NBER WORKING PAPER SERIES

\title{
DOES FINTECH SUBSTITUTE FOR BANKS? EVIDENCE FROM THE PAYCHECK PROTECTION PROGRAM
}

\author{
Isil Erel \\ Jack Liebersohn \\ Working Paper 27659 \\ http://www.nber.org/papers/w27659 \\ NATIONAL BUREAU OF ECONOMIC RESEARCH \\ 1050 Massachusetts Avenue \\ Cambridge, MA 02138 \\ August 2020, Revised December 2020
}

We would like to thank Daniel Green, Greg Howard, Victor Lyonnet, Karen Mills, Bernadette Minton, Claudia Robles-Garcia (discussant), René Stulz, Tejaswi Velayudhan, and participants at the Stanford-Princeton Bendheim Center Corporate Finance and the Macroeconomy conference and seminars at Cambridge, Indiana, Northeastern, Penn State, Oklahoma, Ohio State, and Zurich for very helpful comments. Thanks to May Zhu, Jason Lee and David Xu for excellent research assistance. All errors are our own. The views expressed herein are those of the authors and do not necessarily reflect the views of the National Bureau of Economic Research.

NBER working papers are circulated for discussion and comment purposes. They have not been peer-reviewed or been subject to the review by the NBER Board of Directors that accompanies official NBER publications.

(C) 2020 by Isil Erel and Jack Liebersohn. All rights reserved. Short sections of text, not to exceed two paragraphs, may be quoted without explicit permission provided that full credit, including () notice, is given to the source. 
Does FinTech Substitute for Banks? Evidence from the Paycheck Protection Program

Isil Erel and Jack Liebersohn

NBER Working Paper No. 27659

August 2020, Revised December 2020

JEL No. G00,G01,G2,G21,G23,G28,H12,H2,H3

\begin{abstract}
$\underline{\text { ABSTRACT }}$
New technology promises to expand the supply of financial services to small businesses poorly served by the banking system. Does it succeed? We study the response of FinTech to financial services demand created by the introduction of the Paycheck Protection Program (PPP). We find that FinTech is disproportionately used in ZIP codes with fewer bank branches, lower incomes, and a larger minority share of the population, as well as in industries with little ex ante smallbusiness lending. FinTech's role in PPP provision is also greater in counties where the economic effects of the COVID-19 pandemic were more severe. We estimate that more PPP provision by traditional banks causes statistically significant but economically small substitution away from FinTechs, implying that FinTech mostly expands the overall supply of financial services, rather than redistributing it.
\end{abstract}

Isil Erel

Fisher College of Business

Ohio State University

2100 Neil Avenue

Columbus, OH 43210

and NBER

erel@fisher.osu.edu

Jack Liebersohn

University of California Irvine

cjlieber@uci.edu 


\section{Introduction}

The COVID-19 pandemic created "a crisis like no other," with a projected global economic contraction of 4.9 percent in $2020 .{ }^{1}$ To support small businesses through the crisis, the U.S. government created the Paycheck Protection Program (PPP), which offered guaranteed and potentially-forgivable small-businesses loans to "provide a direct incentive for small businesses to keep their workers on the payroll." ${ }^{2}$ Although the program was administered by the Small Business Administration (SBA), approved financial institutions received applications and distributed the funds. With $\$ 669$ billion disbursed over a period of a few months, the PPP program was unprecedented in speed and scale compared to other small business support programs. ${ }^{3}$ To meet the extraordinary demand for PPP loans, the SBA made the last-minute decision to approve a number of non-traditional lenders specializing in Financial Technology (FinTech) to distribute PPP funds alongside traditional banks. How does credit provision by these non-traditional lenders differ from traditional banks?

This paper examines the effects of this multi-billion-dollar "experiment" to approve FinTech lenders for the PPP program, which provides a unique opportunity to study how FinTech changes access to financial services. Non-traditional and FinTech lenders are a relatively new but rapidly growing phenomenon. How they impact credit access will have important consequences for credit access overall. For example, FinTech firms are currently not allowed to directly participate in important government lending programs, but they may be allowed to do so in the future. ${ }^{4}$ We study how

\footnotetext{
${ }^{1}$ World Economic Outlook Update, International Monetary Fund, June 2020.

${ }^{2} \mathrm{PPP}$ is an important part of the Coronavirus Aid, Relief, and Economic Security (CARES) Act: See https://www.sba.gov/funding-programs/loans/coronavirus-relief-options/paycheck-protectionprogram.

${ }^{3}$ For comparison, the 7 (a) program, which is the main guaranteed lending program from the SBA, has guaranteed between $\$ 10$ billion and $\$ 20$ billion per year since 2010 .

${ }^{4}$ Non-Federally Regulated Lender laws make it hard for pure FinTech lenders to participate in the SBA's 7(a) and 504 programs even if they have a state banking license. Some FinTech firms are
} 
FinTechs differ from traditional banks in terms of not only reaching small businesses with urgent funding needs, but also providing financial services to potential borrowers with limited access to the banking system. We find that FinTech is disproportionately used in areas with fewer bank branches, lower incomes, and a larger minority share of the population, as well as in industries with little ex ante small-business lending and where the economic effects of the COVID-19 pandemic were more severe.

Why was the decision to approve FinTech lenders unusual? Although the role of FinTech has increased in the financial services industry, allowing financial intermediation by FinTech lenders remains controversial. ${ }^{5}$ Regulators have argued that FinTech lenders require more regulation (Brooks and Calomiris, 2020); and lawmakers have been particularly concerned about whether FinTechs act in a more discriminatory way than traditional banks. ${ }^{6}$ Yet FinTechs have argued that they are less discriminatory because they do not rely on relationships or face-to-face interactions with customers. ${ }^{7}$ Understanding whether FinTechs serve traditionally under-served borrowers is important for the future of bank regulation, made particularly relevant by the increased concern that bank regulators have shown in racial and income disparities.

Our findings have implications for how FinTech expansion, if it is allowed, might affect the small business lending market, where SBA-backed loans have material importance. Although we have some evidence on how FinTech lenders fill in the gap created by traditional banks for loans secured with collateral, including mortgages and equipment loans, ${ }^{8}$ we have limited information on how FinTech lenders would do

able to participate in these programs by partnering with a qualifying bank.

${ }^{5}$ See, e.g., Buchak, Matvos, Piskorski and Seru (2018), Chernenko, Erel and Prilmeier (2019), Gopal and Schnabl (2020), Stulz (2019), Liebersohn (2020), and Gopal and Schnabl (2020).

${ }^{6}$ https://cleaver.house.gov/sites/cleaver.house.gov/files/Fintech_Report_1.pdf; https://www.occ.treas.gov/news-issuances/news-releases/2020/nr-occ-2020-112.html.

${ }^{7}$ See https://www.fintechfutures.com/2020/03/can-fintech-eliminate-credit-discrimination/.

${ }^{8}$ See Buchak et al. (2018) for evidence on mortgages and Gopal and Schnabl (2020) for loans in the market for equipment loans. 
for the types of services that rely more on relationships. This setting also provides the rare opportunity to study how past relationships affect the supply of a new financial product. It is unclear if the low level of existing financial services in under-served areas is driven by demand or supply. The exogenous demand shock created by the PPP program and COVID-19 crisis provides an opportunity to understand how the supply of services differs between banks and FinTechs. Further, we can study how this varies for different types of borrowers in the same county at the same time.

Our first question is whether FinTechs provided more access to PPP loans in areas where these loans were needed more, relative to traditional banks. Traditional financial institutions (i.e., depository institutions) have been shown to be inefficient in their allocation of financial services across customers of different sizes, locations, and demographics (Philippon, 2015; Harvey, Santoro and Ramachandran, 2020), and, in the particular case of allocating PPP loans, have been heavily criticized by the popular media for favoring their relationship borrowers at the expense of smaller firms that were hit hardest by the pandemic. ${ }^{9}$ Granja, Makridis, Yannelis and Zwick (2020) show that during Phase 1 of the PPP program, banks did not allocate credit to regions where it was needed. We ask whether the same was true for FinTechs. We show that during Phase 1 of the program, when traditional banks were most constrained, FinTech lenders provided more PPP loans than traditional banks to areas with a worse economic shock. Studying Phase 2 of the program leads to interesting findings as well: While both traditional banks and FinTech lenders provided more PPP loans to the areas with a higher COVID-19 case rate and more unemployment claims, the response of the FinTech lenders was greater than ten times larger economically.

Second, we study whether FinTech lenders provided PPP loans to businesses with little previous access to the banking system, relative to traditional banks. We show

\footnotetext{
${ }^{9}$ E.g., "Banks Gave Richest Clients 'Concierge Treatment' for Pandemic Aid,” NYT, April 2020.
} 
that borrowers with less local access to the traditional banking system were more likely to get FinTech-enabled PPP loans. We also study how FinTechs serve lowincome and non-white borrowers. Comparing borrowers located in the same county, borrowers in ZIP codes with few branches were more likely to get a loan from a FinTech lender. FinTech is also disproportionately used in ZIP codes with lower incomes and a larger minority share of the population. Relative to FinTech lenders, traditional banks provided a higher fraction of PPP loans to firms in industries with stronger ties to the banking system, measured using ex-ante demand for SBA loans relative to new PPP demand. Moreover, one-person firms were more likely to rely on FinTech loans. These findings support the view in the popular press that traditional banks base their PPP loans on past relationships and are geographically constrained by the location of their physical branches, unlike FinTech lenders, which operate mainly online and where prior relationships are less relevant.

Third, we ask whether FinTech lenders "expand the pie" of financial services or merely redistribute it. Even for borrowers that could access traditional banks, FinTechs lenders may be quicker or more convenient, as Buchak et al. (2018) show for mortgage loans, especially during the early phases of the PPP program. But, given our finding that FinTech lending of PPP loans was more common for firms with weaker ties to the banking system, FinTechs may also have provided loans to borrowers who otherwise would not have received them.

To answer this question, we study whether small businesses substitute to FinTech lenders when local banks are less responsive to their demand for PPP loans. A high degree of substitution would mean that FinTech lenders are mostly redistributing which borrowers get loans, whereas less substitution implies that FinTechs are opening up new markets altogether. To measure how much substitution happens, we first create a bank-level measure of PPP responsiveness at the national level by calculating 
how many PPP loans each traditional bank originates per branch. Then, using the ex ante location of each bank's branches or deposits, we predict how much PPP origination we would expect based on the banks that happen to be located in each ZIP code, in an approach that is akin to a shift-share ("Bartik") design. Note that using national lending patterns to predict local bank responsiveness yields variation in traditional banks' PPP lending that is independent of the magnitude of the COVID19 shock and concentrates only on ZIP codes where banks have branches.

We find that FinTech lenders originate more PPP loans per business in ZIP codes where our instrument predicts lower PPP lending by traditional banks. In other words, borrowers respond to a lack of bank PPP provision by somewhat substituting to these other types of financial institutions, despite the fact that many FinTech lenders were granted authorization only during the last few days of the Phase 1 of the PPP. But this substitution, which is significant statistically, is small economically. The number of FinTech loans that are made as a result of this substitution is only 0.3 percent of the decrease in traditional bank lending. Overall, these findings show that FinTech lenders expanded the access to the PPP program but did not close the gap in financial services across regions where banks operate. But, the substitution is likely to be substantially larger in ZIP codes that are under-served by the traditional banking system as this estimate comes from ZIP codes where bank branches are located and the estimates are weighted by the number of branches per ZIP code.

It is important to note that the incentives in play for PPP loan origination are different from standard credit. PPP funds are forgivable in many circumstances and lenders do not bear credit risk. Therefore, our results do not speak to differences between FinTech lenders and traditional banks in evaluating borrowers' creditworthiness, but rather, to the differences in their use of relationships to allocate government-backed credit and in their use of new technology. Banks provide small 
businesses a variety of services, from treasury management to business checking and money market accounts, that are mediated by their relationships with borrowers. These types of services are still mostly provided by banks, but FinTechs are becoming increasingly competitive. The effects of this change are unclear. Furthermore, government-backed credit is an important part of small business borrowing, not only in crisis times. Therefore, our findings have important implications for the potential effects of allowing (more) FinTech lenders to participate in any type of fully or partially-guaranteed government loan program (e.g., SBA 7a loans). ${ }^{10}$ Allowing greater FinTech participation has the potential to increase the efficiency of small business lending even during non-crisis periods.

The rest of the paper is organized as follows. Section 2 reviews the literature on FinTech lending. Section 3 describes the PPP, discusses the data collection process and presents summary statistics. In Section 4, we present our main results on geography of online and nonbank lending. Section 5 addresses whether ZIP codes with less bank branches had more PPP loans by FinTech lenders, controlling for local demographics. In Section 6, we calculate predicted responsiveness of banks to the PPP and then test whether borrowers were more likely to get a FinTech-enabled loan if they are located in ZIP codes where local banks were unlikely to originate PPP loans. Section 7 concludes.

\section{Literature Review}

The literature on FinTech lenders has focused mostly on household finance (see, e.g., Buchak et al. (2018) and Fuster, Plosser, Schnabl and Vickery (2019)), especially mortgage lending, where the role of technology has increased significantly. Authors

\footnotetext{
${ }^{10}$ See, e.g., Craig, Jackson and Thomson (2008) showing positive effects of SBA-backed loans on employment in low-income areas.
} 
find that FinTech lenders process loan applications faster than traditional banks, improving efficiency of financial intermediation in mortgage markets, but they do not necessarily serve underserved borrowers with low access to finance. ${ }^{11}$ Ours is one of the first papers to focus on how FinTechs can provide financial services to small businesses, especially the ones in underserved areas.

Small-business lending is important because it is cash-flow based, unlike mortgages, so it is an area that commercial banks are, theoretically, uniquely suited for (see, e.g., seminal papers by Diamond (1984), Petersen and Rajan (1994)). Banks create and maintain relationships with borrowers and these relationships are particularly important for the types of small and privately held firms that the PPP program targeted. If FinTech lenders can do as well as banks (or better) in serving small businesses, then they are able to compete with traditional banking in one of their core competencies provided they are allowed to. Not relying on branches and relationships, FinTech lenders can also "expand the lending pie" and serve underserved businesses. This is one reason that we specifically focus on whether FinTech lenders provide PPP loans to the types of firms that do not have preexisting relationships with banks. We find that, indeed, FinTech lenders do this.

One important obstacle in research about small businesses is the limited availability of loan-level data on FinTech lending in comparison to bank lending. But in the case of PPP loans, data on the universe of lenders and customers is available, which allows us to speak to the entirety of this market. One paper that studies FinTech lending for small businesses is Gopal and Schnabl (2020), where the sam-

\footnotetext{
${ }^{11}$ There is also a growing literature on peer-to-peer personal loans that use FinTech, testing various predictions on lax screening/bottom fishing or cream skimming, comparing these loans with bank loans (see, e.g., Morse (2015) for a review; de Roure, Pelizzon and Thakor (2018), Di Maggio and Yao (2018), Tang (2019), Vallee and Zeng (2019), Basten and Ongena (2020) for more recent papers). Carlin, Olafsson and Pagel (2020) study the introduction of a mobile application for a financial aggregation platform in Iceland and show resulting reductions in high-interest, unsecured debt and bank fees, improving consumers' well-being.
} 
ple includes only asset-backed loans to purchase durable goods. Unregulated finance companies have traditionally been key players in this market and their role has increased even more after the 2008 Financial Crisis, as shown by the authors. ${ }^{12}$ In the case of PPP, most of the purely online FinTech lenders were introduced to a market -government-subsidized loans- that they have never participated in before and competed with traditional banks, which have traditionally the been primary participants of these programs. We find that FinTech lenders helped significantly in reaching the businesses and areas that were more severely hit by the COVID-19 shock.

Insufficient access to bank credit is one important reason for borrowers to bank with FinTech lenders. This reason has become more important as regulatory constraints during and after the financial crisis have contracted bank lending (Butler, Cornaggia and Gurun, 2016; Mills and Dang, 2020). Balyuk, Berger and Hackney (2020) study commercial loans through online lending platforms and show the importance of banking relationships for small businesses. The authors find that FinTech lending platforms compete with banks on hard-information based loans by out-ofmarket banks, but not necessarily on soft-information based relationship loans by in-market banks to small businesses. We show, in a setting where only hard information matters, that FinTech lenders reach a wider borrower base while banks remain constrained within their branch networks.

There are also several papers that study how FinTechs and nonbanks serve middle market firms. Chernenko et al. (2019) show that nonbanks provide significantly more credit to unprofitable public businesses and that this is because banks' cash-flow loans are subject to tighter regulatory scrutiny. In effect, they find that nonbank

\footnotetext{
${ }^{12}$ See, also, Hanson, Shleifer, Stein and Vishny (2015), Cole, Cumming and Taylor (2019), and Cortes, Demyanyk, Li, Loutskina and Strahan (2020) showing how various nonbank lenders have been filling the gap when large commercial banks faced regulatory constraints and, therefore, had to pull back from commercial lending.
} 
and traditional bank credit markets are highly segmented. We find that though the FinTech-enabled PPP loans only partially substituted for traditional banks' PPP loans to small businesses, they significantly increased PPP loan availability where it was needed the most. ${ }^{13}$

FinTech banks have also been competing aggressively on the funding side of the financial institutions' balance sheet. Abrams (2019) points to the rapid growth in deposit contracts offered by online banks in the past decade: online banks now comprise four of the 30 largest banks by deposits, pay higher deposit rates, and have about the same amount of market power over their depositors as midsize banks do. Given the way the PPP program is structured, having an existing relationship with a bank, even through a simple commercial deposit account should matter.

Lastly, we also contribute to the literature on government interventions - especially, directed lending programs. Such programs can run in a form of a direct subsidy (e.g., Banerjee and Duflo (2014) using data from India) or an indirect subsidy as in a loan guarantee (e.g., Claire, Sraer and Thesmar (2010) using data from France). PPP is also a directed lending program, where the Small Business Administration offered guaranteed and potentially forgivable loans to small businesses, but borrowers applied for and received loans through the system of financial institutions. Therefore, the role of these institutions in this process is essential. Some contemporaneous papers have also studied the PPP program. Cororaton and Rosen (2020) study public firms that got funding through the PPP and received significant media outrage as the program

\footnotetext{
${ }^{13}$ Davydiuk, Marchuk and Rosen (2020) also study commercial lending to middle-market firms, but only by Business Development Companies (BDCs). There are also papers using Dealscan data on larger loans to study loans extended by or sold to nonbanks. For example, Carey, Post, and Sharpe (1998) focus on loans arranged by finance companies. Berlin, Nini and Yu (2018), Lim, Minton and Weisbach (2014), Nadauld and Weisbach (2012), Ivashina and Sun (2011), Massoud, Nandy, Saunders and Song (2011), and Jiang, Li and Shao (2010), Biswas, Ozkan and Yin (2018), Irani, Iyer, Meisenzahl and Peydro (2020) study participation by nonbanks in loans arranged and syndicated by banks.
} 
was aimed to help small businesses. They document that only $13 \%$ of the eligible public firms, which is half of the public firms, end up participating. Li and Strahan (2020) focus on the role of close relationships with banks in accessing the PPP loans. Using preliminary data, Granja et al. (2020) examine whether areas that were more severely hit by the COVID-19 pandemic, as measured by declines in hours worked or business shutdowns, end up getting more allocations. Barrios, Minnis, Minnis and Sijthoff (2020) develop a payroll-based framework and provide preliminary analyses that the state-level funds, which were granted till May 1st, were allocated as predicted by their framework. Moreover, Autor, Cho, Crane, Goldar, Lutz, Montes, Peterman, Ratner, Villar and Yildirmaz (2020) use administrative payroll data and find estimate that the PPP boosted employment at eligible firms by $2 \%$ to $4.5 \%$. Bartik, Bertrand, Cullen, Glaeser, Luca and Stanton (2020) study the effects of PPP on small businesses using a representative national survey. ${ }^{14}$ In this paper, we focus on the differential effect of FinTech lenders in channeling PPP funds.

\section{Payroll Protection Program and Data}

The Paycheck Protection Program (PPP) authorized up to $\$ 669$ billion toward job retention by small businesses. ${ }^{15}$ The program provided loans to small businesses and eligible nonprofit organizations to pay up to eight weeks of payroll costs including benefits, interest on mortgages, rent, and utilities. ${ }^{16}$ With about $\$ 525$ billion approved — 5.2 million loans passed through 5,460 financial institutions - by the final approval

\footnotetext{
${ }^{14} \mathrm{We}$ also contribute to a broader literature studying the consequences of the COVID-19 crisis on financial and capital markets (see e.g., Green and Loualiche (2020), Fahlenbrach, Rageth and Stulz (2020), Pastor and Vorsatz (2020), Halling, Yu and Zechner (2020), and Falato, Goldstein and Hortaçsu (2020)).

${ }^{15}$ Funds were distributed in two phases. $\$ 349$ billion was distributed in Phase 1 over April 3-16, 2020 .

${ }^{16}$ Tribal businesses, self-employed individuals, and independent contractors are also eligible if they meet the PPP's size standards.
} 
date of August 8, the PPP was one of the largest economic stimulus programs in U.S. history. According to data reported by program participants, it supported over 51 million jobs, a majority of small business employment in the United States.

The program was administered by the Small Business Administration (SBA) but loans were allocated through eligible financial institutions. Eligible institutions included any SBA 7(a) lender, federally insured depository institution or credit union, or any other lender that was approved by the SBA and enrolled in the program. Lenders neither charged any fees nor asked for collateral to grant these small business loans. Loans originated prior to June 5 had a maturity of 2 years while those originated after June 5 had a maturity of 5 years. PPP loans carried an interest rate of $1 \%$ but loan repayment was deferred for six months. Most importantly, the loans were fully forgiven if the funds were used at least $60 \%$ for payroll costs, interest on mortgages, rent, and utilities. The majority of loans granted were for less than $\$ 150,000$, with the overall average loan size being $\$ 100,729$.

Our main data source is the database of PPP loans released by the Small Business Administration (SBA). It consists of loan-level data on all PPP loans that were approved by the SBA. The data include some characteristics of borrowers and loans. For loans with a value above $\$ 150,000$, borrower names are available, but the loan amounts are grouped into bins. For smaller loans, the exact dollar amount is available but not the borrower names. The borrower's ZIP code is included and industry information is available at the 6-digit NAICS level for all loans. The SBA also provided the names of the financial institutions (but no other identifiers) that facilitated the loan applications and distributions. ${ }^{17}$

\footnotetext{
${ }^{17}$ News reports have raised concerns about errors in some loans' data fields, especially free-form text fields and information about borrower demographics (Yanofsky, 2020). Our findings do not rely on borrowers' specific address or demographic information. Insofar as there are mistakes in ZIP codes, this would create measurement error in our dependent variables and would not bias the results.
} 
We match this loan-level data to bank identifiers from the Federal Financial Institutions Examination Council (FFIEC) using the lender names provided. ${ }^{18}$ Most of the names are matched using automated name matching. ${ }^{19}$ Lenders which we are not able to match automatically are a combination of non-bank lenders, banks that have duplicate names, and banks that have idiosyncratic names. We therefore hand-match all PPP lenders who originate over 500 PPP loans, classifying separately non-bank lenders and banks which do not have a unique match in the FFIEC database. This procedure allows us to match over $97 \%$ of all PPP loans in the sample. The remaining lenders are mostly small community banks with non-standard names. For the deposit-taking banks, we obtain bank-level characteristics, including bank size, from June 2020 Call reports and data on the number of commercial bank branches by ZIP code from the 2018 FDIC Summary of Deposits database. Then we classify lenders into three categories: Large banks (with assets above $\$ 20 \mathrm{bn}$ ), small banks and credit unions (with assets below $\$ 20 \mathrm{bn}$ ), and FinTech lenders. In most of our analyses, we compare depository financial institutions (including savings institutions and credit unions), henceforth referred to as traditional banks, with FinTech lenders. Note that we treat any unclassified lender as a traditional bank.

We identified Fintech lenders as any unregulated nonbank lender that participated in the program as well as any regulated online direct bank. Specifically, nonbank lenders are non-depository financial institutions, like Kabbage, that generally rely on FinTech in their lending. ${ }^{20}$ These nonbank lenders are not subject to typical bank regulation as they are not financed by deposits. Online banks, however, are

\footnotetext{
${ }^{18}$ Specifically, we use the Attributes File from the end of June, 2020.

${ }^{19}$ We start by searching for exact, unique name matches between the files. For unmatched lenders, we try searching for common variants of their names, such as "N.A." in place of "National Association." PPP lenders whose names match multiple banks are matched to the bank with more branches. Names which remain unmatched are then matched by hand.

${ }^{20}$ Some nonbank lenders in the sample may not necessarily be traditional FinTechs (such as Business Development Corporations), but most are.
} 
regulated deposit-taking banks but with only one administrative branch. They also rely heavily on FinTech for both their lending and deposit taking. Therefore, we classify banks in our sample as online banks if they have one branch only but extended more than 500 PPP loans per branch to exclude small traditional community banks with single branches. ${ }^{21}$ To this sample, we also added a few banks with more than one branch, as identified by Abrams (2019) as online banks. A few examples of these additions are Axos Bank, Capital One Bank, and the TIAA Bank. A full list of our FinTech lenders is provided in the Appendix B. We present results for online banks and nonbank lenders combined as FinTechs, but, in the Appendix Table A3, we also provide our main table with separate columns for these subgroups of institutions since their regulatory treatment is different.

One interesting observation is that two one-branch community banks (Cross River bank and Celtic Bank) partnered heavily with FinTech firms and extended almost 350,000 PPP loans in total. These banks are classified as online banks in our sample. As Stulz (2019) discusses, many purely online FinTech lenders (e.g., LendingClub and Kabbage), which started as peer-to-peer lenders extending only personal loans, have also moved to direct small-business lending over time, through a banking subsidiary or a funding bank partner. Kabbage, which is a nonbank lender, extended about 200,000 loans, making it the fourth largest lender in terms of the number of PPP loans granted. We have three FinTech lenders in top five and four FinTech lenders in top ten PPP lenders by loan count.

Many of our analyses will be at the ZIP code level, in which we aggregate PPP lending based on the borrower's ZIP code. Unless otherwise specified, all estimates and summary statistics are weighted by the number of PPP loans per ZIP code. We

\footnotetext{
${ }^{21}$ In Appendix Table A2, we also provide our main table using a smaller subset of online banks as robustness. See the Appendix for the list of these FinTech lenders.
} 
measure the fraction of nonbank, online, and bank lending by ZIP code for borrowers whose type we have classified. ${ }^{22}$

We match this data to demographic information from the 2000 Decennial Census and the 2014-2018 American Community Survey (ACS) (Manson, Schroeder, Van Riper and Ruggles, 2017). From the Decennial Census, we measure the fraction of the population that is white. From the ACS, we measure total population, median household income, and travel time to work. We recode travel time to create an indicator that measures the fraction of households that report a travel time of over 45 minutes. Census variables are measured by ZIP Code Tabulation Area which we match to ZIP codes. To measure the economic characteristics of firms -i.e., the number and size of establishments - in each ZIP code, we use data from ZIP Business Patterns 2017 data. The average size of establishments is calculated as the total employment divided by the number of establishments in each ZIP code.

We measure the magnitude of the economic shock by county using data from the Opportunity Insights Track the Recovery web site (Chetty, Friedman, Hendren and Stepner, 2020). We focus on two main measures. First, we measure the four-week change in unemployment claims by county as of April 11, 2020. This measure covers the last week before unemployment started rising until the peak level of unemployment claims nationally. Second, we measure the average of the daily count of COVID cases by county in March per 100 people. See Chetty et al. (2020) for more details on these measures.

Summary Statistics by ZIP codes, weighted by PPP loans, are shown in Table 1. ${ }^{23}$ Since we do not have loan amounts for all types of loans - only those with a value below $\$ 150,000$ — our analysis focuses on the number of PPP loans rather than

\footnotetext{
${ }^{22}$ Bank lending measured at the ZIP code level includes some lending by credit unions and saving institutions, which are also depository institutions like commercial banks.

${ }^{23}$ See Table A1 for unweighted statistics.
} 
on their dollar amount. ${ }^{24}$ However, in these types of direct government subsidies, it is at least as important to understand how many firms ended up benefiting from the loan program as the average value of the loan granted. $7 \%$ and $10 \%$ of all PPP loans were processed by nonbank lenders and online banks, respectively. The mean (median) ZIP code had 629 (515) PPP loans. In these ZIP codes, median income is about $\$ 64,000$, only $14 \%$ of the population commute at least 45 minutes per day to work, and $80 \%$ of the population is white. In a typical ZIP code with PPP loans, there are 9.4 bank branches but with a standard deviation of 7.2 branches. Also, note that bank branch summary statistics are shown only for ZIP codes with a non-zero number of branches. A given ZIP code in our sample has 924 establishments and a total population of 13,736 , on average. These areas also had $0.02 \%$ March COVID case rate and $3.35 \%$ unemployment growth. ${ }^{25}$

\section{The Geography of FinTech Lending}

Figure 1 shows the number of PPP loans by lender type between April 3, when the first Phase of the PPP started, and August 8, when the second Phase of the PPP ends. The $\mathrm{X}$-axis of this figure shows the approval date and the $\mathrm{Y}$-axis shows the number of PPP loans approved on each date by lender type. There is a gap between April 16, when PPP Phase 1 ended, and April 27, when Phase 2 began. Most of the PPP lending occurred in Phase 1 and in the beginning of Phase 2.

Media reporting during PPP Phase 1 suggested that smaller banks were better able to process PPP loans than larger banks. The evidence in the upper panel of

\footnotetext{
${ }^{24}$ On average, FinTech lenders originate smaller loans than traditional banks do. The average loan from FinTech lenders supports five jobs the average loan from traditional banks supports twelve jobs, based on borrowers' reports, suggesting that FinTech loans reach smaller businesses.

${ }^{25}$ Unemployment rates, which we can measure only at the county level, are not available everywhere.
} 
this figure supports this view: During the initial weeks of PPP Phase 1, there were significantly more PPP loans arranged by small banks than by large ones. ${ }^{26}$ The difference shrank towards the end of Phase 1, and by late Phase 2, large banks were responsible for more PPP lending than small banks were.

FinTech lenders were responsible for about $16 \%$ of PPP loans overall, with their share increasing in Phase 2 of the program. The right panel of Figure 1 presents the average FinTech fraction of PPP loans by week. The share of loans from FinTech institutions started increasing during the last few days of Phase 1 and significantly accelerated during Phase 2, reaching the majority of overall lending. It is important to note here that many FinTech lenders were approved only during the last few days of Phase 1, likely reducing the total number of PPP loans they could extend before the program expired.

We begin by studying where, on a national basis, FinTech lenders were more widely used relative to traditional banks. We use an independent measure of regional interest in online PPP lending based on Google searches to validate our measure. Specifically, we use Google Trends to calculate, at the state level, variation across states in searches for the phrase "apply for ppp loan online" from March 1, 2020 to August 8, 2020. States with few searches are excluded from the Google Trends data. ${ }^{27}$ Figure 2 shows the relationship between Google searches for online lending and our measure of actual PPP loans, with missing states located at zero. The relationship is positive and statistically significant whether or not we include states that have too few searches to include. This finding is supported by information we learned from

\footnotetext{
${ }^{26}$ We believe that the unmatched banks in our sample are more likely to be credit unions and community banks than larger national banks, because community banks have names which are more difficult to match unambiguously (e.g., "First Bank" and "Farmers and Merchants Bank" each refer to many possible banks). Therefore, the difference between small and large banks may actually be understated in this figure.

${ }^{27}$ The top state for online searches is Georgia. The largest nonbank FinTech lender in the sample is Kabbage, Inc., which is based in Atlanta.
} 
discussions with FinTech lenders, that Google searches were an important way that small businesses found out about FinTech loans.

Next, we turn to the geographic distribution of PPP loan provision by FinTech lenders measured using the SBA loan database and our classification of FinTech lenders. The specifications in Table 2 explore the geographic correlates of PPP loan provision. Our first question is whether FinTech PPP loans flowed unconditionally to the areas that needed it most in both periods, and if they differed in this regard from traditional banks. To measure which areas were most in need of PPP loans, we use county-level variables collected by Chetty et al. (2020): the increase in unemployment claims rate between the months of March and April and the average COVID-19 case rate per 100 people in March. Our other variables are measured at the ZIP code level. We control for the log number of establishments by ZIP code to avoid a mechanical relationship between the number of establishments and the number of loans. Regressions are run at the ZIP code-level and estimates are weighted by total PPP loans by ZIP code. Robust standard errors are reported. Our dependent variable is the log of total PPP loans by traditional banks or by FinTech lenders.

During Phase 1, traditional banks did not provide PPP financing to the regions with higher case rates or higher unemployment, as already found by Granja et al. (2020). In fact, traditional banks provided fewer PPP loans to counties which needed it more, along both measures (see Column (2) of Table 2). By contrast, FinTech loans did flow to areas with a worse COVID shock and a worse economic shock, despite the fact that majority of them got approval in the last few days of Phase 1 (see Column (1)). The difference between FinTech lenders and traditional banks is also economically meaningful in Phase 1. According to the coefficients in Columns (1) and (2), each additional COVID case per 100 people was associated with 4 log-points less PPP lending from traditional banks but no less from FinTech lenders. One more 
percentage point increase in unemployment was associated with 0.07 log points less traditional bank lending and 0.07 log points more FinTech lending.

One possible explanation for the failure of traditional banks in reaching the areas hit more by the COVID-19 shock during Phase 1 could be their ability or preference to start PPP lending in areas with bank branches. If areas underserved by bank branches are also hit worse, we would find the findings presented in Column (2) troubling, given the intention of the PPP to reach to worse-hit businesses as quickly as possible, but not surprising. In Column (3), we limit the sample of PPP loans to those extended by traditional banks that have at least one branch in the same ZIP code as the PPP loans, and hence focus on lending by local traditional banks. Findings are similar: even local banks with close-by branches did not provide PPP financing to the regions with higher case rates or higher unemployment during Phase 1 of the PPP.

Another possible reason that traditional banks did not lend more in the worst-hit areas may be that they faced different incentives than FinTech firms, for example because stricter anti-money-laundering compliance made it more expensive for traditional banks to acquire new customers than FinTechs. However, many regulated banks partnered with FinTech firms to originate PPP loans for their commercial banking customers, suggesting that they wanted to originate PPP loans quickly but did not have the capacity to do so themselves. These traditional banks may have faced internal barriers to adopting new technologies even when they were motivated to do so.

During Phase 2, as shown in the last two columns of Table 2, PPP loans flowed towards areas that needed more assistance both from traditional banks and from online banks/online lenders. However, even then, FinTechs were more responsive to financial need than traditional banks were. The coefficient on the average case 
rate is more than ten times larger for FinTech loans than traditional bank loans. During Phase 2, each additional COVID case per 100 people was associated with 5 log points more FinTech loans and 0.3 log points more loans from traditional banks. In Column 6, where we concentrate on the local traditional banks, the difference drops but only slightly, with the order of magnitude of almost ten times smaller than the FinTech lenders' response. Supporting the widely-reported problems with banks' ability to provide PPP loans to areas that needed it during Phase 1 of the program, our findings seem to indicate that FinTech lenders were better able to respond to local demand.

\subsection{Demographics of FinTech Loans}

Figure 3 is a county-level graph showing the fraction of PPP loans coming from each type of institution for the entire United States. Here, we consider a combination of Phase 1 and Phase 2 loans. There are clear patterns visible in this figure. Major metropolitan areas, such Atlanta, Miami, Houston and Chicago, as well as both coasts, have a high fraction of their PPP loans originated by FinTech lenders. Urban parts of New Mexico, Colorado and Arizona also have significant FinTech PPP loan origination.

Our main question is whether FinTech lenders provided PPP loans to borrowers poorly-served by the banking system. At a descriptive level, the national data suggest that FinTech loans were most common in areas that are already well-served by the banking system: coasts and major metro areas. However, there may be other important factors that vary by state or county, such as differences in COVID-19 awareness or differences in historical FinTech marketing, that make this hard to interpret. Therefore, our next step will be to study differences in FinTech PPP lending 
by borrowers located in the same county, in order to control for these sorts of regional differences.

To build intuition for our within-county results, we consider the geography of lending by online banks and nonbanks in the city of Chicago. Figure 4 shows the distribution of PPP loans for ZIP codes in Cook County, which includes most of the Chicago metro population. We are interested in understanding the distribution of FinTech loans in relation to demographic differences in ZIP codes within the metropolitan area. As shown in the left panel of this figure, Cook County is characterized by large differences in income by ZIP code. The North Shore is high-income and also mostly white, as are the western parts of Cook County. South Chicago has lower median incomes. Differences in income are sharp across neighborhood boundaries.

These differences manifest themselves in differences in the proportion of PPP loans that come from FinTech lenders. The right panel of Figure 4 shows the fraction of PPP loans which we classify as coming from FinTechs. Businesses in the richer ZIP codes of Chicago mostly get their loans from traditional banks and credit unions, whereas the lower-income areas get a higher fraction of their loans from FinTechfocused online banks and nonbanks. We have created similar maps for other major metro areas and found similar patterns.

One possible reason for local differences in FinTech PPP lending by ZIP code is the variation in the location of traditional bank branches, a topic we now turn to. ZIP codes with more bank branches are known to have more competitive banking markets and hence better credit access. The relationship between bank branches, and FinTech lending is shown in Figure 5, which is a binscatter plot. The left panel of this figure, labeled "National", uses pooled ZIP code data from the entire country. On the X axis, we show the average (log) bank branches per ZIP code, where ZIP codes are grouped into vintiles and the logarithms are in base-10 to make interpretation simpler. 
The $\mathrm{Y}$ axis shows the fraction of Fintech PPP loans for each vintile. Based on the national patterns Figure 3, we should not be surprised to see that regions with more bank branches also had a higher share of Fintech lending. Looking across regions, relationship between bank branches and FinTech lending is generally upward-sloping (although it is not perfectly linear).

But when we look within-county, these patterns are reversed: ZIP codes with fewer branches have a higher fraction of FinTech loans. The right panel of Figure 5 conditions on county fixed effects and hence uses only within-county variation in bank branches by ZIP code. Here, there is a clear negative relationship bank branches and the fraction of FinTech loans. In other words, although online banks and nonbank lenders have a larger presence in parts of the country with more traditional banking, they disproportionately serve under-resourced areas when we look within a county.

We next turn to linear regressions to quantify this evidence and to distinguish between the separate effects of bank branch location and demographic differences in loan demand.

\section{Branch Distance and FinTech Lending}

A large body of research in banking shows that banks are more likely to have a lending relationship with borrowers located physically close to their branches. If banks prioritized PPP lending to customers with existing bank relationships, we would expect to see a correlation between the number of bank branches and the likelihood that borrowers got their PPP loans from a traditional bank.

Confirming the pattern in Figure 5, this result is shown in Table 3. Bivariate regressions, shown in Columns (1) and (2), show an economically and statistically significant effect of bank branches on FinTech lending. A one log-point increase in 
the number of bank branches decreases the fraction of FinTech loans by about 0.02 . Since the median fraction of FinTech loans is about 15\%, this means that doubling the number of bank branches in a ZIP code is associated with a decrease in the FinTech share of about $13.3 \%$ of the median.

The finding in Table 3 controls for county fixed effects, which eliminates many potential confounding variables that might vary by region. Nonetheless, we might worry that the relationship between bank branches and traditional bank lending is due to omitted demand factors, such as the types of businesses located there, rather than due to the supply of loans from traditional banks. Yet, adding local demographic and income controls slightly increases the estimated relationship between bank branches and the FinTech share of borrowers. In Columns (3) and (4), we add median income, the fraction of white population in a ZIP code, and the fraction of population with a commute above 45 minutes. Within a county, areas with lower incomes, longer commutes, and more non-white people have a larger FinTech share of PPP loans. And conditional on these controls, the coefficient on log bank branches rises from 0.02 to 0.025 . FinTech lenders, therefore, reached not only to areas more severely hit by the virus, but also to under-served borrowers with limited access to the banking system.

As a robustness check, Table A4 in the Appendix shows results from similar specifications at the loan level. The results are similar. Loan level specifications allow us to control for differences in borrower characteristics which may affect the riskiness of the loans. All the specifications in this table control for borrower industry. Since we use 6-digit NAICS industries, the NAICS industry likely proxies for many types of borrower differences. We also add controls for average establishment size and local demographics. Throughout, the effect of bank branches on the Fintech share remains negative and statistically significant, and it does not change much even after including 
NAICS6 fixed-effects.

Next, we exploit variation in PPP demand coming from regional variation in the COVID-19 shock to show that, relative to FinTechs, banks' supply of PPP loans is more elastic in regions where there are more branches. To test this prediction, we interact the magnitude of the shock with the density of bank branches and study the supply response by FinTechs versus banks. We use the following regression specification:

$$
\text { FinTechShare }_{z c}=\beta_{1} \text { Branches }_{z}+\beta_{2} \text { Shock }_{c} \times \text { Branches }_{z}+\delta_{c}+\varepsilon_{z}
$$

where $z$ indexes ZIP codes, $c$ indexes counties, and $\delta_{c}$ are county fixed effects. ${ }^{28}$ We are interested in $\beta_{2}$, the coefficient on interaction between the COVID-19 shock and the number of bank branches. We expect that a high shock provokes a greater response by banks relative to FinTechs in areas with many bank branches. Therefore, we expect $\beta_{2}$ to be negative. We again measure the COVID-19 shock using both the number of cases per 100 people in March and the rise in unemployment at the county level between the months of March and April.

The results are shown in Table 4, where Columns (1) and (3) use Commuting Zone rather than county fixed effects so that the Case Rate and Unemployment Rate main effects - which are measured at the county level - are identified. We find that the effect of COVID cases on FinTech lending is reduced in areas with more bank branches (see Column (2)). Interpreting the coefficients in the first two columns, one more case per 1,000 people means that FinTechs originate about 9 percentage points more of the local PPP loans on average. But in areas with one log point more branches, the effect of each COVID case on the FinTech fraction is reduced by

\footnotetext{
${ }^{28}$ Since the COVID-19 shock is measured at the county level, county fixed effects mean we do not include a main effect for the COVID shock in the baseline specification.
} 
about $10 \%$. In other words, adding one log point more branches reduces the effect of one COVID case per 1,000 from about 9 percentage points to about 8 percentage points. Likewise, bank branches intermediate the effect of unemployment on PPP loans. Shown in Columns (3) and (4), areas where the unemployment rate grew by 1 percentage point more had 1.5 percentage points more of their PPP loans coming from FinTechs. But if the number of bank branches rises by one log-point, the effect of a 1 percentage point increase in the unemployment rate on the FinTech share falls to 1.0 percentage points. Overall, these results show that banks' supply of PPP loans was more elastic in regions with more branches, highlighting again the importance of branch networks for banks' provision of financial services.

Borrowers in low-income regions learned about the PPP program from a variety of sources, including messaging from their regular banks and from public service announcements from the SBA and nonprofits. ${ }^{29}$ Informal discussions with FinTech lenders suggest two important ways that borrowers learned about FinTech lenders in particular. First, many borrowers, especially those who were denied loans by a traditional bank, searched for PPP loans online and came across FinTech lenders. Second, community banks without the capacity to make loans themselves may have referred borrowers to the FinTechs, in some cases without informing the FinTech lenders that they were doing this.

\subsection{Banking Relationships and FinTech Lending}

The statistics so far have provided evidence that in lower-income areas and in areas with fewer banks, more borrowers turned to FinTech loans for their PPP. But, we are also interested in directly answering the question of whether firms with less $e x$

\footnotetext{
${ }^{29}$ One prominent nonprofit was Our Fair Share, which was founded by musician Sean Combs to provide information about PPP and other government programs to minority entrepreneurs.
} 
ante exposure to the formal banking system were more likely to turn to these types of lenders. Our results for branch density provide evidence that bank relationships matter, but we would like to show this by showing the same thing for different types of borrowers that are located in the same ZIP code.

To measure exposure to the formal banking system, we measure pre-COVID banking system access at the industry level. To do this, we use SBA data on the 7(a) program from the years 2018 and 2019. The 7(a) program is the main lending program that the SBA uses to support small businesses. Since it is administered through the same types of institutions as the PPP program, firms in industries which previously used 7(a) loans are likely to have ex ante banking relationships. Therefore, we measure which industries disproportionately got PPP loans relative to how many SBA loans they previously used. Small businesses in industries which demanded many PPP loans, but previously had few SBA 7(a) loans, are unlikely to have strong relationships with banks. On the other hand, small businesses in industries where SBA 7(a) loans are common are more likely to have a formal banking relationship. Therefore, we measure the log ratio of PPP loans in the sample relative to SBA 7(a) loans from the previous two years. We construct this measure at the 6-digit NAICS industry level.

These estimates are shown in Table 5. As shown in Column (1) of this table, businesses in industries with a higher PPP demand shock relative to the SBA 7(a) lending quantity were more likely to go online or turn to nonbanks. Applying the estimates in Column 1, firms in an industry with 10 percent more PPP loans than SBA loans would get 0.2 percentage points more of their PPP loans from FinTechs, relative to firms in an industry with the same number of PPP as SBA loans. While 0.2 percentage points sounds small, it is economically meaningful given that only 10 percent of all PPP loans are from FinTechs. Column (2) adds controls for fixed 
effects at the NAICS 2-digit level. We do this to ensure the robustness of the results to differences in industry exposure to COVID at the sector level. When we add these controls, the coefficient on the SBA loan access measure increases and remains highly statistically significant.

Another measure of exposure to traditional banking is presented in Columns (3)(4) of Table 5: whether firms that applied for the PPP loans are structured as a sole proprietorship or as a self-employed individuals. These one-person firms, which are unlikely to have a formal borrowing relationship with a traditional bank, are more than 20 percentage points more likely to borrow from a FinTech PPP provider. As expected, this effect is very significant not only statistically but also economically.

In the last two columns of Table 5, we use industry-level employment growth, which is a four-week change in unemployment insurance claims by April 11. We find that firms from industries with larger growth around the COVID-19 shock rely less on FinTech PPP loans. In other words, FinTech PPP loans have reached to harder-hit industries that were underserved by banks.

These results show that banks base their lending on past relationships and constrain themselves around their branches. FinTech lenders do not have geographic constraints based on the presence of loan officers or physical bank branches. Despite this observation, there are a few reasons to think that relationships, or something akin to relationships, might matter for FinTechs. First, borrowers might not know about the possibility of getting a PPP loan through an online bank unless they have done it before. Therefore, areas with many FinTech borrowers in the past might be disproportinately served by FinTech lenders during the PPP program. Second, small businesses might use online banks for other types of financial services, such as deposits or credit cards. Such borrowers might also trust the same firms to supply PPP loans for them. In both cases, we would expect areas with a large historical FinTech 
presence to have more PPP loans as well.

To understand whether "relationships" matter for FinTechs, we measure how many SBA 7(a) loans came from FinTechs in the years before the COVID crisis and ask whether this is associated with borrowers getting PPP loans from FinTechs as well. To do this, we match lender names from the 7(a) program to the classification which we create for the PPP program. Less than $2 \%$ of 7 (a) loans made from 2018-2019 come from lenders which did not make PPP loans, and which we therefore do not classify. Among 7(a) loans we do classify, about 5\% come from online banks and about $1.5 \%$ come from nonbank lenders. Many of the most important nonbank FinTech lenders, such as Kabbage, Inc., have no history of originating 7(a) loans at all. There is substantial heterogeneity by ZIP code in terms of the share of loans coming from FinTech lenders.

The estimates in Table 6 Columns (1)-(2) present the relationship between the share of 7(a) loans in each ZIP code coming from FinTech lenders and the share of PPP loans coming from them. We find that geographic persistence matters for FinTech lenders, but it is not the only important factor. On the one hand, the estimated effect of 7(a) lending from FinTechs on the FinTech share of PPP loans is statistically significant at the $5 \%$ level when we include control variables. On the other hand, the point estimate is economically very small - not different from zero without controls and 0.012 including controls. Moreover, the coefficient on log bank branches is still significant when we include the FinTech fraction of 7(a) loans as a control variable and the estimate is similar to the estimates in Table 3.

Although we show that FinTech lenders serve underserved populations and areas, an important potential constraint for borrowers' access to FinTech lenders is the access to information online. Therefore, we explore next whether FinTech lending is larger in areas with larger fraction of population with a computer. Both regressions 
are run at the ZIP code level with country fixed effects included and presented in the last two columns of Table 6. Interestingly, we find a negative and significant coefficient in Column (3); however, in Column (4), this coefficient turns to be positive and significant when we control for the median income and other demographic characteristics of the Zip codes in addition to the number of bank branches. A possible reason for this is that computer access is positively correlated with income, banking system access, etc., so without controlling for these factors, the estimated relationship between computer access and FinTech usage is spuriously negative.

Another possible explanation for FinTech lending in areas underserved by banks is selective and increased advertising in these areas during the COVID-19 shock. From our discussions with FinTech lenders, we learned that FinTechs did not engage in particular marketing pushes during this time relative to traditional banks. But we would like to confirm this using the data. Using time-series data from Kantar Media, as provided by Adspender, we analyze commercial and business financial services advertising dollars by FinTech lenders and traditional Lenders through July, 2020. We hand-matched our bank and top-30 FinTech PPP lenders to create this sample and present monthly averages of advertisement dollars by quarter in the Appendix Figure A1. We find a general decline in FinTech advertising dollars, which are mostly dedicated to national, cable-TV advertising, in 2020 with no change in this trend during COVID-19 period. If anything, we see an increase in spending on ads by traditional banks in the third quarter of 2020 .

Overall, in this section, we find that geography matters more for traditional banks than for FinTech lenders. While FinTech lenders do provide PPP loans in areas that they have lent in the past, this effect is not strong. Rather, they focus on facilitating transactions for any borrower with a computer. 


\section{How Substitutable are FinTech Loans?}

An important question is whether FinTechs expand the overall loan supply by providing PPP loans to new types of borrowers who otherwise would not have gotten PPP loans, or their presence just causes substitution away from banks. We have shown that borrowers in regions with fewer branches or with weaker ties to the banking system are more likely to borrow from FinTech lenders. But this finding does not necessarily imply that FinTechs lend to a new segment of borrowers. If borrowers with weak ties to the banking system find FinTech lending more convenient, then it is possible that they get PPP loans from FinTechs that they would have gotten from banks if FinTech loans had not been available. On the other hand, if FinTechs expand access into an altogether new market, then we would expect little substitution between FinTech lenders and banks.

To shed light on this question, we study whether borrowers substitute to FinTech lenders in traditional banking regions, where traditional banks' PPP loan supply is constrained. If the FinTech and traditional bank markets are relatively segmented, then we would not expect much substitution between FinTech and traditional bank PPP loans in these regions with bank branches. On the other hand, if borrowers easily substitute between banks and non-banks, then any reduction in traditional bank lending should lead to a substantial substitution to FinTech lenders.

Our identification strategy relies on differences in traditional banks' overall supply of PPP loans. According to widespread news reports around the time of Phase 1 of PPP, some banks were able to handle the surge in PPP demand much better than others. We exploit these differences at the national level and create a measure of predicted bank responsiveness that will allow us to distinguish the possible explanations for our findings. The advantage of measuring predicted responsiveness, rather than 
realized responsiveness, is that the realized level of responsiveness of local banks may be a function of the magnitude of the COVID shock in each region, which may also have direct effects on the types of PPP loans that borrowers choose. By predicting banks' responsiveness based on their national lending patterns, we hope to create a measure of traditional bank PPP lending that is independent of the number of COVID-19 cases.

We create our predicted-PPP measure in two steps. First, we measure PPP loans per bank branch (PPP loans divided by the number of bank branches) at the bank level nationally in all counties where a bank has branches. This is our measure of bank "responsiveness" to the PPP program. In the second step, we calculate the average responsiveness by ZIP code of banks located there. This yields a prediction for the amount of PPP lending that will take place in each ZIP code. We take the log of this measure to calculate the log predicted number of PPP loans by ZIP code..$^{30}$

Note that in constructing our predicted-PPP measure, we drop each state's own branches and loans and do the calculations in step 1 using loans from other states. This leaving-one-out approach also ensures that our measure of bank responsiveness in each state is independent of COVID-19 conditions in that state. ${ }^{31}$ In this way, we create a measure akin to a shift-share shock (Bartik, 1991), where we quantify the degree of responsiveness, at the bank level, to the PPP program.

Following Goldsmith-Pinkham, Sorkin and Swift (2020), our identifying assumption is that our measure is independent of unobserved variables which affect the relative demand of FinTech versus traditional bank loans. To support this assump-

\footnotetext{
${ }^{30}$ Since this variable is only available in ZIP codes with bank branches, estimates using predicted loan amounts will have about half as many observations as the previous tables.

${ }^{31}$ To see why this is important, consider the example of two community banks, each located in only one state, where their states have different PPP demand shocks. The bank located in the high-shock state would appear more "responsive" to the program because it would originate more loans per branch. But, this would be coming from differences in loan demand, not loan supply.
} 
tion, we show that predicted PPP lending is independent of the magnitude of the COVID-19 shock. Table A5 in the Appendix verifies that the predicted lending measure is independent of our two proxies for the size of the COVID shock - the average COVID case rate in March and the increase in the unemployment claims rate from March 15 to April 11. Ideally, we would measure these variables at the ZIP code level and use specifications with county fixed effects. Since these variables are only available at the county level, this table uses Commuting Zone fixed effects instead. We also include specifications which control for the number of bank branches per ZIP. $^{32}$

Next, we verify that in ZIP codes with more responsive banks, more PPP lending is provided overall. These results are shown in Appendix Table A7. For this table, we include county fixed effects and weight estimates by the number of branches in the ZIP code. We also add the total number of bank branches as an additional control variable. The variable of interest is labeled "Predicted PPP" and it measures the log predicted number of PPP loans by ZIP code. Since online banks have few branches but many loans, they would appear highly responsive. To minimize the influence of any online banks we may have missed in our classification, this table also shows versions of the predicted measure at different levels of Winsorization. The coefficients on the Winsorized measures are larger than the un-Winsorized ones, as we expect, given that this measure minimizes the influence of online banks. Therefore, we use the predicted PPP measure that is Winsorized at the bank level at the 95th percentile.

Table 7 shows the effect of predicted PPP bank lending on the log number of

\footnotetext{
${ }^{32} \mathrm{An}$ implicit assumption of this approach is that banks are more likely to make PPP loans in ZIP codes where their branches are located. Table A6 of the Appendix shows that this is true. Column 1 shows the results of bank-by-ZIP code level specifications for each ZIP code where banks have branches. We also show results from a specification with ZIP code fixed effects in Column 2. The large positive coefficient in this column means that, within ZIP code, banks with more branches originate more PPP loans. Finally, Column 3 adds bank fixed effects, so the results are driven by within-bank, cross-ZIP code variation. The coefficient does not vary much across columns.
} 
FinTech loans per establishment. In Column (1), we present the bivariate relationship; in Column (2), we add the total number of bank branches as an additional control variable; and, in Column (3), we add further demographic controls. Estimates are weighted by establishments per ZIP code; but, weighting by PPP loans per ZIP code or using $\log (\mathrm{PPP} /$ Establishments $)$ as a dependent variable yields similar results. The negative, statistically significant coefficients in this table means that ZIP codes with more responsive traditional banks have a lower number of loans from FinTech lenders. In ZIP codes where local banks are predicted to make more PPP loans, there is less FinTech PPP lending per establishment. ${ }^{33}$

While the results in this table are statistically significant, the degree of substitution between FinTechs and traditional banks is economically small. According to our preferred specification, shown in Column (3), the elasticity of FinTech lending with respect to predicted traditional bank lending is approximately -0.04 . This coefficient indicates that a 10 percent decrease in traditional bank lending causes approximately a 0.4 percent increase in FinTech lending. Since FinTech lending is about 15 percent of overall PPP lending, the number of FinTech loans that are made as a result is only 0.3 percent of the decrease in traditional bank lending.

This finding indicates that substitution from traditional banks to FinTechs is not enough to substantially replace traditional bank PPP loans that are not made because banks were not responsive to the program. We conclude that the FinTech and traditional bank lending markets are relatively segmented; and FinTech lenders supply services to a new and relatively distinct market than traditional banks. An important note, however, is that these estimates come from ZIP codes where bank branches are located, and they are weighted by the number of branches per ZIP code.

\footnotetext{
${ }^{33}$ In Table A8, we show that similar results hold when limited to PPP loans made during Phase 2 of the program, when FinTech lenders had full approval to participate.
} 
Substitution may be larger in ZIP codes where fewer branches operate -i.e., the ZIP codes where FinTech loans are more common.

\section{Conclusion}

This papers studies whether FinTech lenders provide access to financial services for regions and borrowers that are not served by the traditional banking system. When we compare different regions of the country, these FinTech online banks and nonbank lenders are concentrated in coastal areas and cities - regions that have better access to banks and better access to financial services.

Within counties, however, FinTech lenders disproportionately serve industries and ZIP codes with less access to traditional finance. ZIP codes with fewer bank branches, lower median income, and larger fraction of the minority population get more of their PPP loans from these types of new lenders. Across industries, firms in industry codes that previously got fewer SBA loans were more likely to get their PPP loans from FinTech lenders. Finally, we show that in ZIP codes where traditional banks keep branches but end up not participating in PPP origination, only a small fraction of local small businesses turned to FinTech online banks and nonbanks instead.

This paper systematically studies the first government program where traditional banks and FinTech lenders have can be compared in terms of their responsiveness to the demand by small businesses for exactly the same type of financial service. Therefore, it has important policy implications, which speak to allowing (more) FinTech lenders in a timely manner to participate in any type of fully or partially-guaranteed government loan program (e.g., SBA 7a loans) to increase the efficiency of small-

business lending not only during crises but also in non-crises periods. Understanding exact mechanisms, whereby FinTech companies are able to provide services to bor- 
rowers underserved by the traditional banking system, is a valuable topic for future research. Moreover, in this paper, we have focused on online FinTech lenders which do not engage in traditional banking. But traditional banks may also use technologyenabled credit scoring or loan application mechanisms. Whether they do so in a different way than specialized FinTech lenders is also fruitful area for future research. 


\section{Author Affiliations}

Isil Erel

Ohio State University, NBER, and ECGI

Jack Liebersohn

University of California Irvine 


\section{References}

Abrams, Eliot, "Assessing Bank Deposit Market Power Given Limited Consumer Consideration," 2019. University of Chicago Working Paper.

Autor, David, David Cho, Leland Crane, Mita Goldar, Byron Lutz, Joshua Montes, William Peterman, David Ratner, Daniel Villar, and Ahu Yildirmaz, "An Evaluation of the Paycheck Protection Program Using Administrative Payroll Microdata," 2020. MIT Working Paper.

Balyuk, Tetyana, Allen Berger, and John Hackney, "What is Fueling FinTech Lending? The Role of Banking Market Structure," 2020. Emory University Working Paper.

Banerjee, Abhijit and Esther Duflo, "Do Firms Want to Borrow More? Testing Credit Constraints Using a Directed Lending Program," Review of Economic Studies, 2014, 81, 572-607.

Barrios, John, Michael Minnis, William Minnis, and Joost Sijthoff, "Assessing the Payroll Protection Program: A Framework and Preliminary Results," 2020. University of Chicago Working paper.

Bartik, Alexander W, Marianne Bertrand, Zoë B Cullen, Edward L Glaeser, Michael Luca, and Christopher T Stanton, "How are small businesses adjusting to covid-19? early evidence from a survey," Technical Report, National Bureau of Economic Research 2020.

Bartik, Timothy J, "Who benefits from state and local economic development policies?," 1991.

Basten, Christoph and Steven Ongena, "The impact of a FinTech platform matching mortgage lenders with borrowers online on bank competition, diversification and automation opportunities," 2020. University of Zurich Working Paper.

Berlin, Mitchell, Greg Nini, and Edison Yu, "Concentration of Control Rights in Leveraged Loan Syndicates," 2018. Federal Reserve Bank of Philadelphia Working Paper.

Biswas, Swarnava, Neslihan Ozkan, and Junyang Yin, "Real Effects of Nonbank Lending," 2018. University of Bristol Working Paper.

Brooks, Brian and Charles Calomiris, "Fintech Can Come Out of the Shadows," WSJ Opinion, 2020.

Buchak, Greg, Gregor Matvos, Tomasz Piskorski, and Amit Seru, "Fintech, regulatory arbitrage, and the rise of shadow banks," Journal of Financial Economics, 2018, 130, 453-483. 
Butler, Alexander, Jess Cornaggia, and Umit Gurun, "Do Local Capital Market Conditions Affect Consumers' Borrowing Decisions?" Management Science, 2016, 63, 3999-4446.

Carlin, Bruce, Arna Olafsson, and Michaela Pagel, "FinTech and Consumer Well-Being in the Information Age," 2020. UCLA Working Paper.

Chernenko, Sergey, Isil Erel, and Robert Prilmeier, "Why Do Firms Borrow Directly from Nonbanks?," 2019. NBER Working Paper.

Chetty, Raj, John N Friedman, Nathaniel Hendren, and Michael Stepner, "How did covid-19 and stabilization policies affect spending and employment? a new real-time economic tracker based on private sector data," Technical Report, National Bureau of Economic Research 2020.

Claire, Lelarge, David Sraer, and David Thesmar, Entrepreneurship and Credit Constraints Evidence from a French Loan Guarantee Program 2010. NBER Working Paper.

Cole, Rebel, Douglas Cumming, and Jon Taylor, "Does FinTech Compete with or Complement Bank Finance?," 2019. Working paper.

Cororaton, Anna and Samuel Rosen, "Public Firm Borrowers of the US Paycheck Protection Program," 2020. SMU Working Paper.

Cortes, Kristle, Yuliya Demyanyk, Lei Li, Elena Loutskina, and Philip Strahan, "Stress Tests and Small Business Lending," Journal of Financial Economics, 2020, 136, 260-279.

Craig, Ben, William Jackson, and James Thomson, "Credit Market Failure Intervention: Do Government Sponsored Small Business Credit Programs Enrich Poorer Areas?," Small Business Economics, 2008, 30, 345-360.

Davydiuk, Tetiana, Tatyana Marchuk, and Samuel Rosen, "Direct Lending in the U.S. Middle Market," 2020. Carnegie Mellon University Working Paper.

de Roure, Calebe, Loriana Pelizzon, and Anjan Thakor, "P2P lenders versus banks: Cream skimming or bottom fishing?," 2018. Washington University Working Paper.

Diamond, Douglas, "Financial Intermediation and Delegated Monitoring," The Review of Economic Studies, 1984, 51, 393-414.

Fahlenbrach, Rüdiger, Kevin Rageth, and René M Stulz, "How valuable is financial flexibility when revenue stops? Evidence from the Covid-19 crisis," Technical Report, National Bureau of Economic Research 2020. 
Falato, Antonio, Itay Goldstein, and Ali Hortaçsu, "Financial Fragility in the COVID-19 Crisis: The Case of Investment Funds in Corporate Bond Markets," Technical Report, National Bureau of Economic Research 2020.

Fuster, A., M. Plosser, P. Schnabl, and J. Vickery, "The role of technology in mortgage lending," Review of Financial Studies, 2019, 32, 1854-1899.

Goldsmith-Pinkham, Paul, Isaac Sorkin, and Henry Swift, "Bartik Instruments: What, When, Why, and How," American Economic Review, 2020.

Gopal, Manasa and Philipp Schnabl, "The Rise of Finance Companies and FinTech Lenders in Small Business Lending," 2020. New York University Working Paper.

Granja, Joao, Christos Makridis, Constantine Yannelis, and Eric Zwick, "Did the Paycheck Protection Program Hit the Target?," 2020. University of Chicago Working Paper.

Green, Daniel and Erik Loualiche, "Local Government Finances and Balanced Budgets in the COVID-19 Crisis," Available at SSRN 3651605, 2020.

Halling, Michael, Jin Yu, and Josef Zechner, "How Did COVID-19 Affect Firms' Access to Public Capital Markets?," The Review of Corporate Finance Studies, 2020 .

Hanson, Samuel G., Andrei Shleifer, Jeremy C. Stein, and Robert W. Vishny, "Banks as patient fixed-income investors," Journal of Financial Economics, 2015, 117, 449-469.

Harvey, Campbell, Joey Santoro, and Ashwin Ramachandran, "DeFi and the Future of Finance," 2020. Duke University Working Paper.

Irani, Rustom, Rajkamal Iyer, Ralf Meisenzahl, and Jose-Luis Peydro, "The Rise of Shadow Banking: Evidence from Capital Regulation," 2020. Working Paper.

Ivashina, Victoria and Zheng Sun, "Institutional demand pressure and the cost of corporate loans," Journal of Financial Economics, 2011, 99, 500-522.

Jiang, Wei, Kai Li, and Pei Shao, "When shareholders are creditors: Effects of the simultaneous holding of equity and debt by non-commercial banking institutions," Review of Financial Studies, 2010, 23, 3595-3637.

Li, Lei and Philip Strahan, "Who Supplies PPP Loans (And Does It Matter)? Banks, Relationships and the COVID Crisis," 2020. Boston University Working Paper. 
Liebersohn, Jack, "Are Retail Banking Markets Still Local? Quasi-Experimental Evidence from Bank Mergers," 2020. Ohio State University Working Paper.

Lim, Jongha, Bernadette A. Minton, and Michael S. Weisbach, "Syndicated loan spreads and the composition of the syndicate," Journal of Financial Economics, 2014, pp. 45-69.

Maggio, Marco Di and Vincent Yao, "FinTech borrowers: Lax-Screening or cream-skimming?," 2018. HBS Working Paper.

Manson, Steven, Jonathan Schroeder, David Van Riper, and Steven Ruggles, "IPUMS National Historical Geographic Information System: Version 12.0 [Database]," Minneapolis: University of Minnesota, 2017, 39.

Massoud, Nadia, Debarshi Nandy, Anthony Saunders, and Keke Song, "Do hedge funds trade on private information? Evidence from syndicated lending and short-selling," , Journal of Financial Economics, 2011, 99, 477-499.

Mills, Karen and Annie Dang, "Building Small Business Utopia: How Artificial Intelligence and Big Data Can Increase Small Business Success In Big Data in Small Business," 2020. Harvard Business School Working Paper.

Morse, Adair, "Peer-to-Peer Crowdfunding: Information and the Potential for Disruption in Consumer Lending," Annual Review of Financial Economics, 2015, 7, 463-482.

Nadauld, Taylor D. and Michael S. Weisbach, "Did securitization affect the cost of corporate debt?," Journal of Financial Economics, 2012, 105, 332-352.

Pastor, Lubos and M Blair Vorsatz, "Mutual fund performance and flows during the COVID-19 crisis," Technical Report, National Bureau of Economic Research 2020.

Petersen, Mitchell and Raghuram Rajan, "The Benefits of Lending Relationships: Evidence from Small Business Data," Journal of Finance, 1994, 1, 3-37.

Philippon, Thomas, "Has the US Finance Industry Become Less Efficient? On the Theory and Measurement of Financial Intermediation," American Economic Review, 2015, 105, 1408-1438.

Stulz, Rene, "FinTech, BigTech, and the Future of Banks," Journal of Applied Corporate Finance, 2019, 31, 86-97.

Tang, H., "Peer-to-Peer Lenders versus Banks: Substitutes or Complements?," The Review of Financial Studies, 2019, 32, 1900-1938. 
Vallee, B. and Y. Zeng, "Marketplace lending: A new banking paradigm?," Review of Financial Studies, 2019, 32, 1939-1982.

Yanofsky, David, "Here's what we know is wrong with the PPP data," 2020. 


\section{Figures}

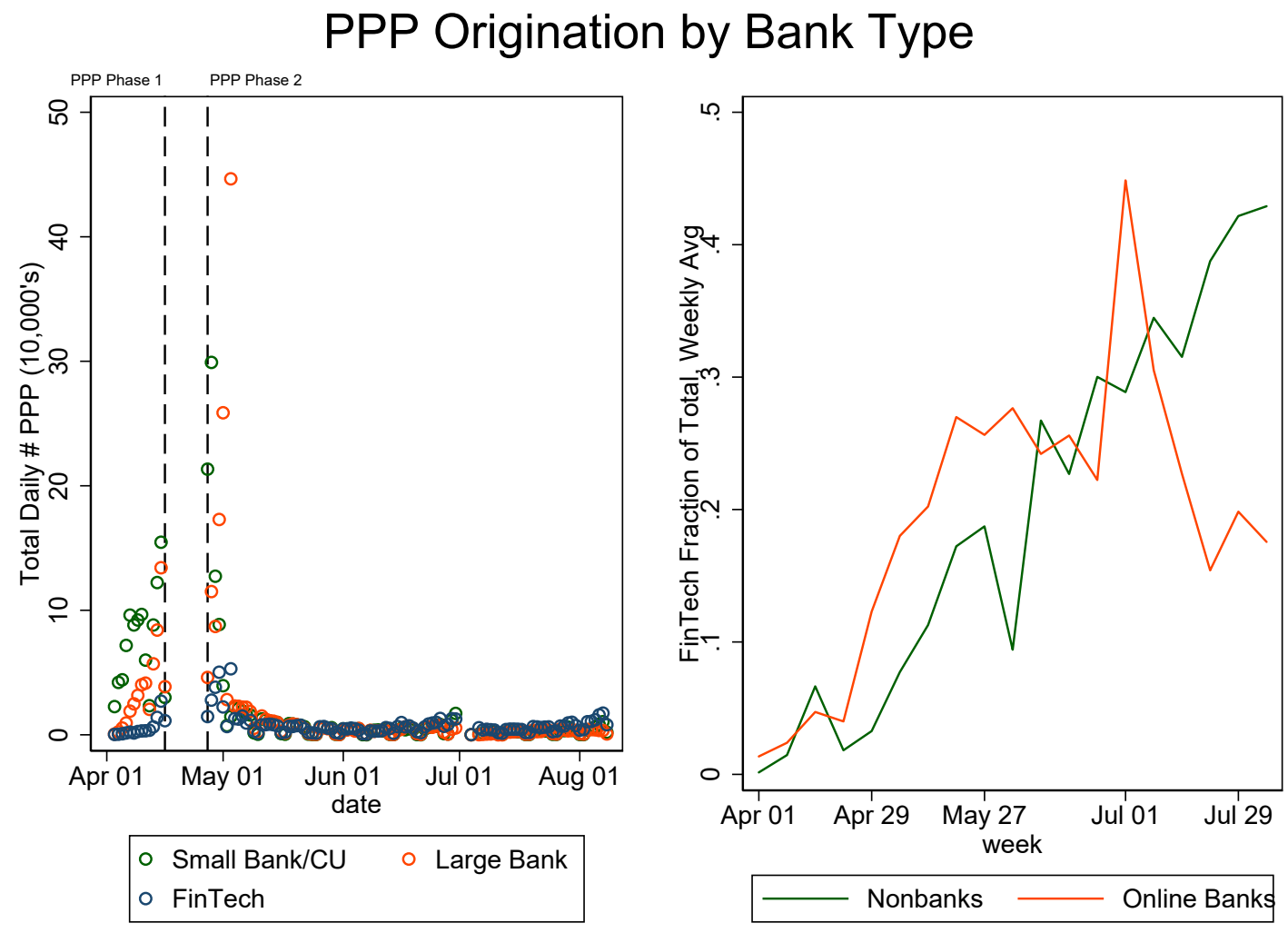

Figure 1: PPP Lending by Day and Type of Institution. Panels show the number of PPP loans given by various lenders daily between April 3 and August 8, 2020. "Large banks" are banks with more than $\$ 20$ billion in assets, "Small Bank/CU" includes all other lenders except FinTech, including unclassified lenders. Source: Calculated from SBA PPP Loan Databse. 


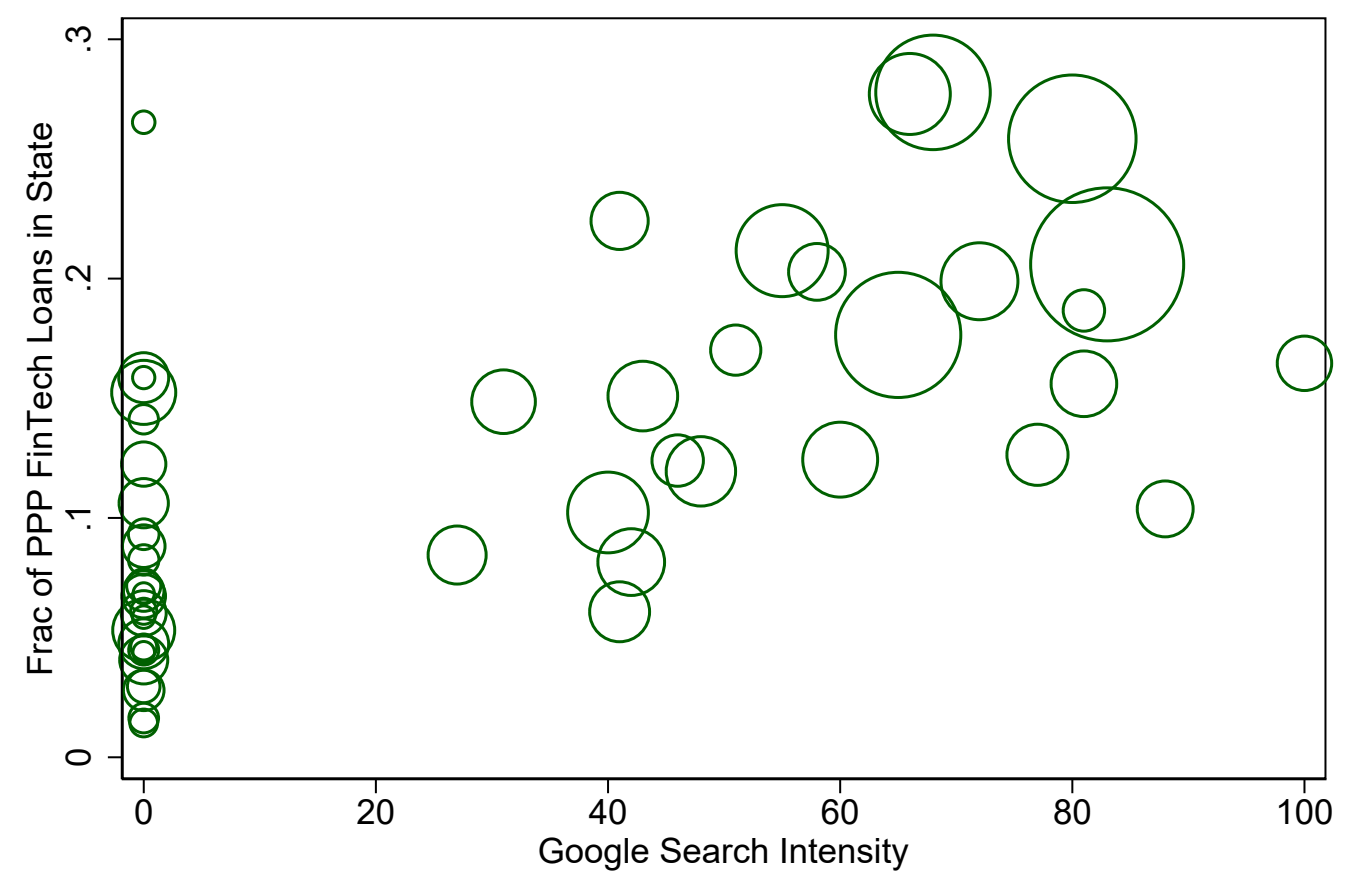

Source: Google Trends. Searches for "apply ppp loan online" from 3/1/20 to 8/8/20.

Each circle represents a state. Weighted by the total number of PPP loans in each state.

Figure 2: Google Searches for Online PPP Loans. 
FinTech Lending by County

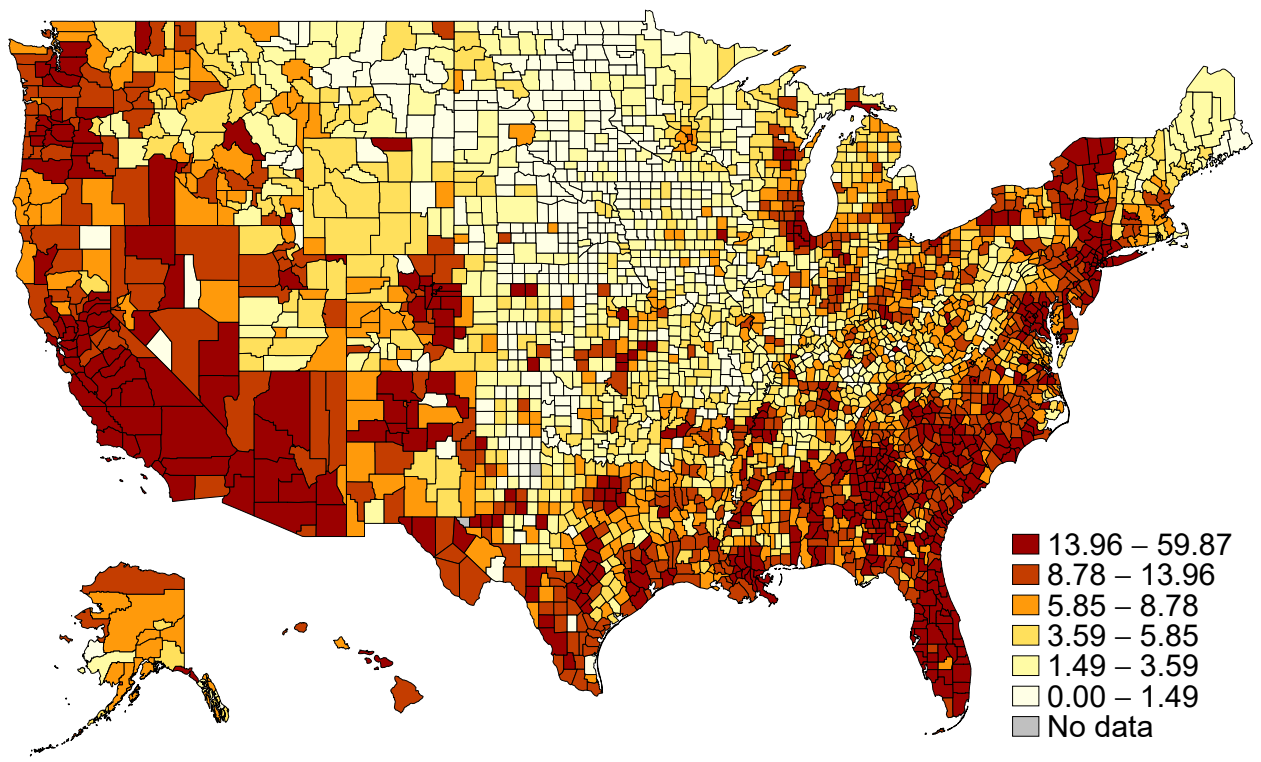

Figure 3: Fraction of PPP Loans from FinTech Lenders, U.S. Counties 


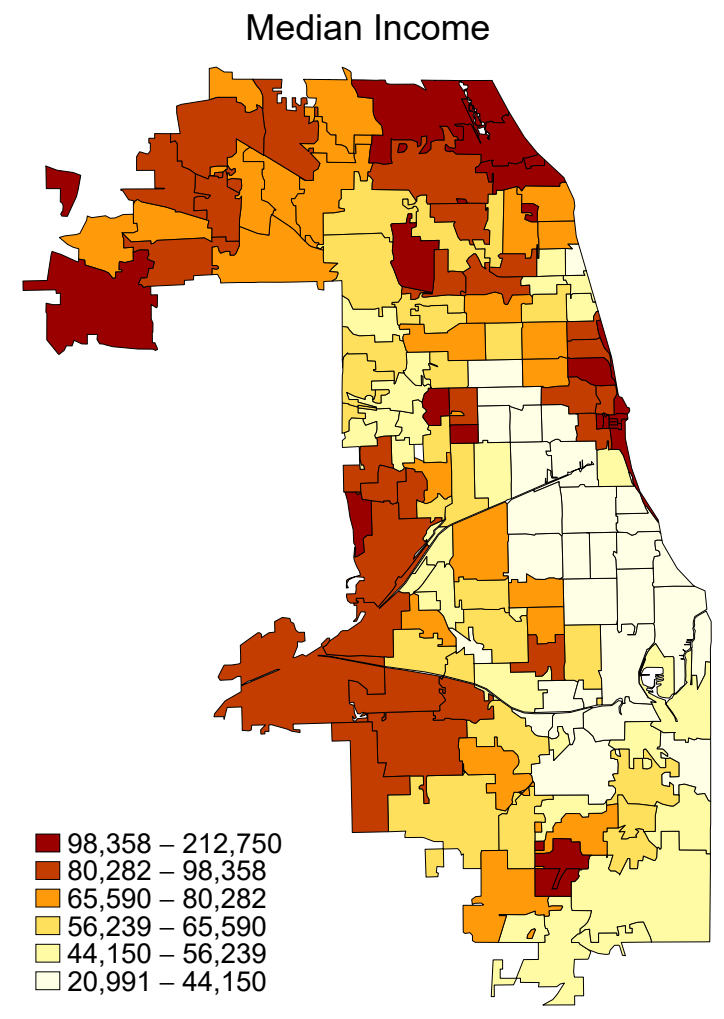

FinTech Lending by ZIP Code

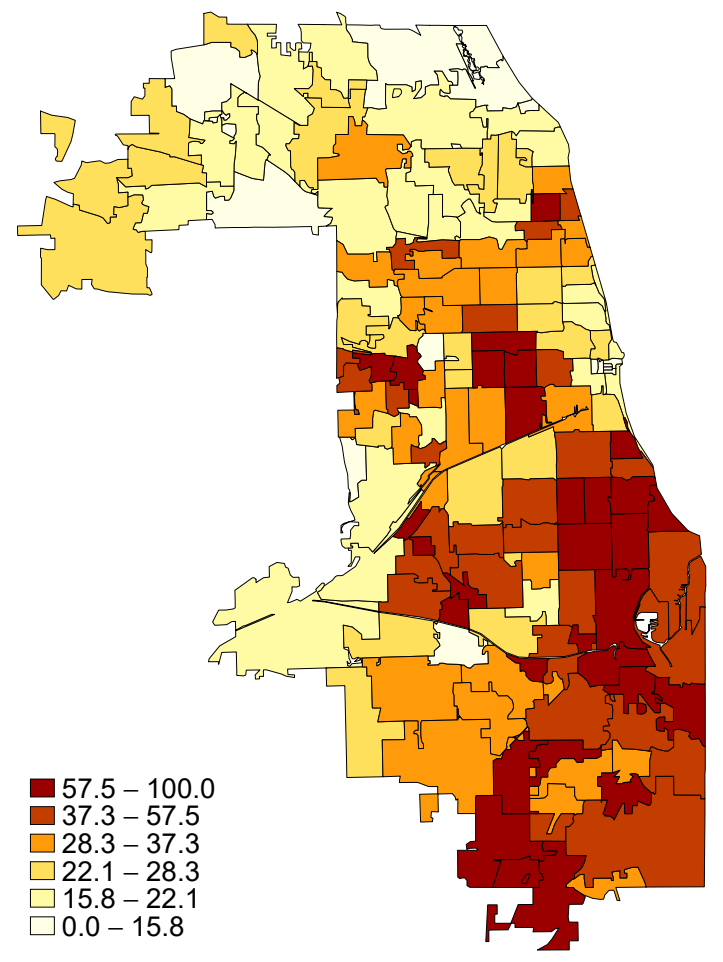

Figure 4: Fraction of PPP Loans from FinTech Lenders, Chicago ZIP Codes. 


\section{PPP Loans and Log Bank Branches}
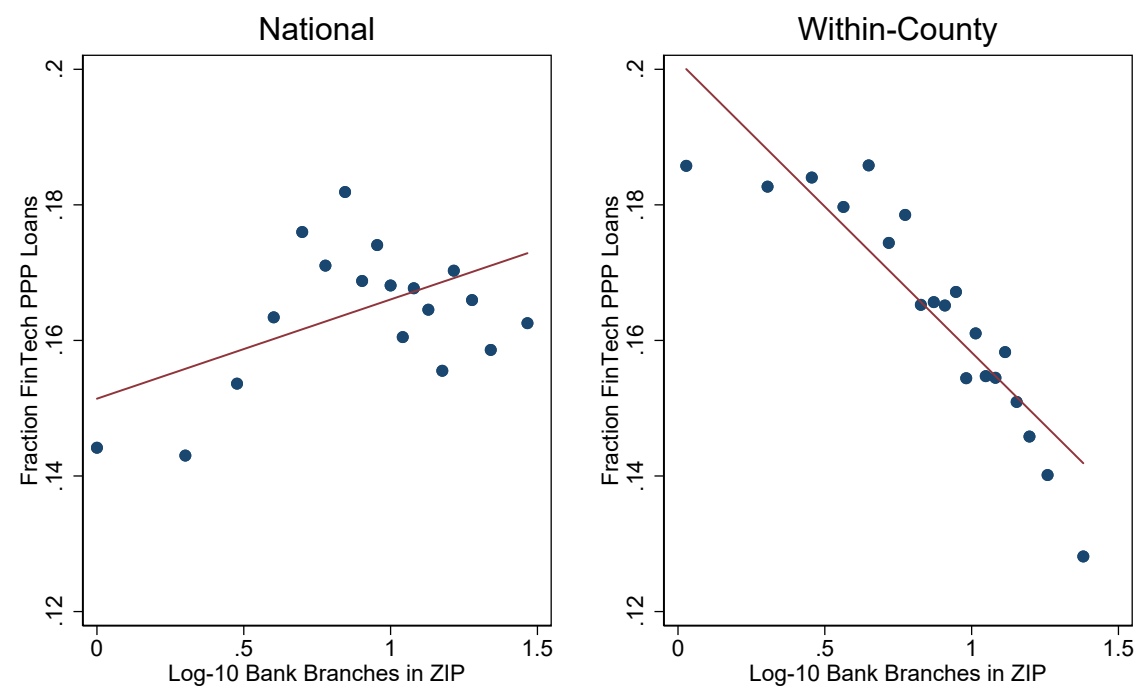

Source: Calculated from FDIC Summary of Deposits and SBA PPP Database. Weighted by PPP loans per Zip code.

Figure 5: Lending Share and Log Bank Branches. 


\section{Tables}

Table 1: Summary Statistics by ZIP Code

\begin{tabular}{lcccc}
\hline & & & & \\
& Mean & Std. Dev & Median & Count \\
\hline Frac Nonbank & 0.07 & 0.06 & 0.05 & 36,675 \\
Frac Online Bk & 0.10 & 0.07 & 0.09 & 36,675 \\
Total FinTech PPP Fraction & 0.16 & 0.12 & 0.15 & 36,675 \\
Frac Bk/CU & 0.83 & 0.12 & 0.84 & 36,675 \\
Num. PPP Lns & 628.56 & 534.53 & 515.00 & 36,675 \\
Median Income & $70,469.32$ & $29,818.04$ & $63,945.00$ & 30,002 \\
Frac. 45m+ Commute & 0.17 & 0.10 & 0.14 & 31,190 \\
Frac. White & 0.74 & 0.21 & 0.80 & 31,501 \\
Total Pop & $13,735.63$ & $9,091.73$ & $12,730.00$ & 31,565 \\
Num. Bk Branches & 9.44 & 7.21 & 8.00 & 19,404 \\
Avg COVID Case Rate & 0.02 & 0.04 & 0.00 & 35,749 \\
Unemp. Growth & 3.35 & 1.83 & 3.01 & 17,176 \\
Num. Estabs & 924.14 & 782.22 & 771.00 & 33,955 \\
\hline
\end{tabular}

Weighted by PPP loans per zip code. Bank branches are for ZIP codes that have at least one branch. Unemployment data is not available for all regions. Source: Calculated from SBA PPP database, FDIC SOD, Decennial Census/ACS, County Business Patterns. 
Table 2: Geographic Correlates of PPP Provision

\begin{tabular}{lcccccc}
\hline & $(1)$ & $(2)$ & $(3)$ & $(4)$ & $(5)$ & $(6)$ \\
& Log PPP & Log PPP & Log PPP & Log PPP & Log PPP & Log PPP \\
& FinTech & Trad. Bk & Local Bk & FinTech & Trad. Bk & Local Bk \\
& Phase 1 & Phase 1 & Phase 1 & Phase 2 & Phase 2 & Phase 2 \\
\hline Avg Case Rate & -0.035 & $-4.17^{* * *}$ & $-2.97^{* * *}$ & $4.94^{* * *}$ & $0.28^{* * *}$ & $0.54^{* * *}$ \\
& $(0.25)$ & $(0.23)$ & $(0.32)$ & $(0.19)$ & $(0.077)$ & $(0.15)$ \\
Change in Unemployment & $0.072^{* * *}$ & $-0.071^{* * *}$ & $-0.14^{* * *}$ & $0.14^{* * *}$ & $0.033^{* * *}$ & $0.020^{* * *}$ \\
& $(0.0078)$ & $(0.0056)$ & $(0.012)$ & $(0.0088)$ & $(0.0025)$ & $(0.0046)$ \\
Log Establishments & $1.07^{* * *}$ & $0.89^{* * *}$ & $1.00^{* * *}$ & $1.07^{* * *}$ & $0.97^{* * *}$ & $1.24^{* * *}$ \\
& $(0.015)$ & $(0.0066)$ & $(0.017)$ & $(0.0086)$ & $(0.0033)$ & $(0.0077)$ \\
Constant & $-5.27^{* * *}$ & $-0.85^{* * *}$ & $-2.37^{* * *}$ & $-3.47^{* * *}$ & $-0.97^{* * *}$ & $-3.41^{* * *}$ \\
& $(0.094)$ & $(0.040)$ & $(0.10)$ & $(0.055)$ & $(0.020)$ & $(0.049)$ \\
\hline Observations & 6432 & 14724 & 7742 & 10866 & 15639 & 8224 \\
$R^{2}$ & 0.562 & 0.748 & 0.392 & 0.714 & 0.913 & 0.778 \\
\hline
\end{tabular}

ZIP code level specifications showing the relationship between COVID-19 shock and the degree of PPP origination, for traditional banks and for FinTech lenders. "Local Banks" are traditional banks, where the sample of PPP loans is limited to those coming from a bank that has a branch in the same ZIP code as the PPP loan. Robust standard errors. Estimates are weighted by PPP loans per ZIP code. Data calculated from Chetty et al. (2020) and SBA PPP loan data. 
Table 3: Number of Branches in the ZIP Code and FinTech PPP Lending Shares

\begin{tabular}{|c|c|c|c|c|}
\hline & $\begin{array}{c}(1) \\
\text { FinTech } \\
\text { PPP } \\
\text { Fraction }\end{array}$ & $\begin{array}{c}(2) \\
\text { Bank } \\
\text { PPP } \\
\text { Fraction }\end{array}$ & $\begin{array}{c}(3) \\
\text { FinTech } \\
\text { PPP } \\
\text { Fraction }\end{array}$ & $\begin{array}{c}(4) \\
\text { Bank } \\
\text { PPP } \\
\text { Fraction }\end{array}$ \\
\hline Log Branches & $\begin{array}{c}-0.019^{* * *} \\
(0.0010)\end{array}$ & $\begin{array}{l}0.020^{* * *} \\
(0.0010)\end{array}$ & $\begin{array}{c}-0.025^{* * *} \\
(0.0013)\end{array}$ & $\begin{array}{l}0.026^{* * *} \\
(0.0013)\end{array}$ \\
\hline Log Med. Inc & & & $\begin{array}{c}-0.012^{* * *} \\
(0.0035)\end{array}$ & $\begin{array}{l}0.014^{* * *} \\
(0.0035)\end{array}$ \\
\hline Frac Commute $45+\mathrm{m}$ & & & $\begin{array}{l}0.19^{* * *} \\
(0.014)\end{array}$ & $\begin{array}{c}-0.20^{* * *} \\
(0.014)\end{array}$ \\
\hline Frac White & & & $\begin{array}{l}-0.18^{* * *} \\
(0.0089)\end{array}$ & $\begin{array}{c}0.18^{* * *} \\
(0.0088)\end{array}$ \\
\hline Log Population & & & $\begin{array}{l}0.025^{* * *} \\
(0.0011)\end{array}$ & $\begin{array}{r}-0.025^{* * *} \\
(0.0012)\end{array}$ \\
\hline Establishments Per Cap. & & & $\begin{array}{l}-0.0049 \\
(0.0051)\end{array}$ & $\begin{array}{c}0.0059 \\
(0.0054)\end{array}$ \\
\hline Constant & $\begin{array}{c}0.20^{* * *} \\
(0.0022)\end{array}$ & $\begin{array}{c}0.79^{* * *} \\
(0.0022)\end{array}$ & $\begin{array}{l}0.22^{* * *} \\
(0.035)\end{array}$ & $\begin{array}{l}0.75^{* * *} \\
(0.035)\end{array}$ \\
\hline Observations & 35937 & 35937 & 28850 & 28850 \\
\hline$R^{2}$ & 0.706 & 0.684 & 0.808 & 0.790 \\
\hline County FEs & $\mathrm{X}$ & $\mathrm{X}$ & $\mathrm{X}$ & $\mathrm{X}$ \\
\hline
\end{tabular}

ZIP code level specifications showing the relationship between the share of FinTech PPP lending and the number of bank branches per ZIP code. Robust standard errors. Estimates are weighted by PPP loans per ZIP code. Data calculated from Chetty et al. (2020) and SBA PPP loan data. 
Table 4: Increases in County Unemployment and PPP Origination

\begin{tabular}{|c|c|c|c|c|}
\hline & $\begin{array}{c}(1) \\
\text { FinTech } \\
\text { PPP } \\
\text { Fraction }\end{array}$ & $\begin{array}{c}(2) \\
\text { FinTech } \\
\text { PPP } \\
\text { Fraction }\end{array}$ & $\begin{array}{c}(3) \\
\text { FinTech } \\
\text { PPP } \\
\text { Fraction }\end{array}$ & $\begin{array}{c}(4) \\
\text { FinTech } \\
\text { PPP } \\
\text { Fraction }\end{array}$ \\
\hline Case Rate & $\begin{array}{c}0.89^{* * *} \\
(0.24)\end{array}$ & & & \\
\hline Log Branches & $\begin{array}{c}-0.017^{* * *} \\
(0.0028)\end{array}$ & $\begin{array}{c}-0.017^{* * *} \\
(0.0031)\end{array}$ & $\begin{array}{c}-0.018^{* * *} \\
(0.0039)\end{array}$ & $\begin{array}{c}-0.00074 \\
(0.0080)\end{array}$ \\
\hline Case Rate $\times$ Log Branches & & $\begin{array}{c}-0.097^{* *} \\
(0.047)\end{array}$ & & \\
\hline Unemp. Chg & & & $\begin{array}{l}0.016^{* * *} \\
(0.0047)\end{array}$ & \\
\hline Unemp. Chg $\times$ Log Branches & & & & $\begin{array}{c}-0.0054^{* * *} \\
(0.0018)\end{array}$ \\
\hline Constant & $\begin{array}{c}0.18^{* * *} \\
(0.0068)\end{array}$ & $\begin{array}{c}0.20^{* * *} \\
(0.0060)\end{array}$ & $\begin{array}{l}0.16^{* * *} \\
(0.016)\end{array}$ & $\begin{array}{c}0.22^{* * *} \\
(0.0085)\end{array}$ \\
\hline $\begin{array}{l}\text { Observations } \\
R^{2} \\
\text { County FEs } \\
\text { CZ FEs }\end{array}$ & $\begin{array}{l}35727 \\
0.604\end{array}$ & $\begin{array}{c}35749 \\
0.702 \\
\mathrm{X}\end{array}$ & $\begin{array}{c}17173 \\
0.588 \\
X\end{array}$ & $\begin{array}{c}17176 \\
0.713 \\
X\end{array}$ \\
\hline \multicolumn{5}{|c|}{$\begin{array}{l}\text { Specifications showing the relationship between the share of FinTech PPP } \\
\text { lending and ZIP code level statistics interacted with the change in unemploy- } \\
\text { ment and change in case rate. Columns (1) and (3) use Commuting Zone fixed } \\
\text { effects because the case rate and change in unemployment are observed at the } \\
\text { county level. Standard errors clustered by county. Estimates are weighted } \\
\text { by PPP loans per ZIP code. Data calculated from the FDIC Summary of } \\
\text { Deposits database and SBA PPP loan data. }\end{array}$} \\
\hline
\end{tabular}


Table 5: FinTech Lending and Firm Relationships

\begin{tabular}{lcccccc}
\hline & $(1)$ & $(2)$ & $(3)$ & $(4)$ & $(5)$ & $(6)$ \\
& FinTech & FinTech & FinTech & FinTech & FinTech & FinTech \\
& PPP & PPP & PPP & PPP & PPP & PPP \\
& Loan & Loan & Loan & Loan & Loan & Loan \\
\hline Log(PPP/SBA 7a) & $0.023^{* *}$ & $0.029^{* * *}$ & & & & \\
& $(0.0097)$ & $(0.011)$ & & & & \\
One-Pers. Firm & & & $0.22^{* * *}$ & $0.21^{* * *}$ & & \\
& & & $(0.016)$ & $(0.013)$ & & \\
Industry Emp. Growth & & & & & $-0.22^{* *}$ & $-0.33^{* * *}$ \\
& & & & & $(0.085)$ & $(0.081)$ \\
Constant & & & & & & \\
& $0.076^{* *}$ & 0.050 & $0.12^{* * *}$ & $0.12^{* * *}$ & $0.35^{* * *}$ & $0.44^{* * *}$ \\
& $(0.037)$ & $(0.044)$ & $(0.0055)$ & $(0.0052)$ & $(0.076)$ & $(0.068)$ \\
\hline Observations & 4863168 & 4863168 & 5076115 & 5076115 & 4035347 & 4035347 \\
$R^{2}$ & 0.113 & 0.133 & 0.161 & 0.173 & 0.121 & 0.142 \\
Zip FEs & $\mathrm{X}$ & $\mathrm{X}$ & $\mathrm{X}$ & $\mathrm{X}$ & $\mathrm{X}$ & $\mathrm{X}$ \\
NAICS2 FEs & & $\mathrm{X}$ & & $\mathrm{X}$ & & \\
\hline
\end{tabular}

Loan-level specifications showing the relationship between FinTech loans and proxies for borrowers' ability to rely on loan relationships. Dependent variable is an indicator equal to 1 if a loan is originated by a FinTech firm. $\log (\mathrm{PPP} / \mathrm{SBA} 7 \mathrm{a})$ measures the number of PPP loans scaled by the number of SBA 7(a) loans in the years 2018-2019, measured at the NAICS 6-digit level. One-Pers. firm is an indicator for sole proprieterships and individuals as indicated in the PPP data. Industry emp. growth measures employment growth by 3-digit NAICS industry between the March and April Current Employment Statistics. Standard errors double-clustered by NAICS 6-digit industry and ZIP code. 
Table 6: Local Technology Use and PPP Lending

\begin{tabular}{|c|c|c|c|c|}
\hline & $\begin{array}{c}(1) \\
\text { FinTech } \\
\text { PPP } \\
\text { Fraction }\end{array}$ & $\begin{array}{c}(2) \\
\text { FinTech } \\
\text { PPP } \\
\text { Fraction }\end{array}$ & $\begin{array}{c}(3) \\
\text { FinTech } \\
\text { PPP } \\
\text { Fraction }\end{array}$ & $\begin{array}{c}(4) \\
\text { FinTech } \\
\text { PPP } \\
\text { Fraction }\end{array}$ \\
\hline 7(a) Share & $\begin{array}{c}0.0048 \\
(0.0075)\end{array}$ & $\begin{array}{c}0.012^{* *} \\
(0.0056)\end{array}$ & & \\
\hline Fraction w Desktop & & & $\begin{array}{c}-0.25^{* * *} \\
(0.014)\end{array}$ & $\begin{array}{c}0.071^{* * *} \\
(0.020)\end{array}$ \\
\hline Log Med. Inc & & $\begin{array}{c}-0.012^{* * *} \\
(0.0038)\end{array}$ & & $\begin{array}{c}-0.026^{* * *} \\
(0.0044)\end{array}$ \\
\hline Frac Commute $45+\mathrm{m}$ & & $\begin{array}{l}0.20^{* * *} \\
(0.017)\end{array}$ & & $\begin{array}{l}0.19^{* * *} \\
(0.014)\end{array}$ \\
\hline Frac White & & $\begin{array}{l}-0.18^{* * *} \\
(0.0097)\end{array}$ & & $\begin{array}{l}-0.18^{* * *} \\
(0.0094)\end{array}$ \\
\hline Log Branches & & $\begin{array}{c}-0.026^{* * *} \\
(0.0014)\end{array}$ & & $\begin{array}{c}-0.025^{* * *} \\
(0.0013)\end{array}$ \\
\hline Log Population & & $\begin{array}{l}0.028^{* * *} \\
(0.0015)\end{array}$ & & $\begin{array}{c}0.024^{* * *} \\
(0.0012)\end{array}$ \\
\hline Establishments Per Cap. & & $\begin{array}{c}-0.0014 \\
(0.0050)\end{array}$ & & $\begin{array}{l}-0.0059 \\
(0.0054)\end{array}$ \\
\hline Constant & $\begin{array}{c}0.17^{* * *} \\
(0.0011)\end{array}$ & $\begin{array}{l}0.19^{* * *} \\
(0.040)\end{array}$ & $\begin{array}{l}0.36^{* * *} \\
(0.011)\end{array}$ & $\begin{array}{l}0.33^{* * *} \\
(0.040)\end{array}$ \\
\hline Observations & 15376 & 14946 & 31316 & 28846 \\
\hline$R^{2}$ & 0.690 & 0.812 & 0.720 & 0.809 \\
\hline County FEs & $\mathrm{X}$ & $\mathrm{X}$ & $\mathrm{X}$ & $\mathrm{X}$ \\
\hline
\end{tabular}

Estimates show the relationship between ZIP-level measures of technology use and the FinTech fraction of PPP loans. "7(a) Share" measures the fraction of 7 (a) loans in the ZIP code coming from FinTech lenders as identified in the PPP data in the years 2018-2019. "Fraction w Desktop" is the fraction of households in the ZIP code with a desktop computer, as reported in the 2014-2018 ACS. Data calculated from SBA 7(a) and PPP data, and US Census/ACS data. Robust standard errors. 
Table 7: Effect of Predicted Bank PPP on Total PPP Per Establishment

\begin{tabular}{|c|c|c|c|}
\hline & (1) & $(2)$ & $(3)$ \\
\hline & $\begin{array}{l}\text { FinTech PPP/ } \\
\text { Establishments }\end{array}$ & $\begin{array}{l}\text { FinTech PPP/ } \\
\text { Establishments }\end{array}$ & $\begin{array}{l}\text { FinTech PPP/ } \\
\text { Establishments }\end{array}$ \\
\hline Log Pred. PPP & $\begin{array}{c}-0.10^{* * *} \\
(0.021)\end{array}$ & $\begin{array}{c}-0.043^{* *} \\
(0.020)\end{array}$ & $\begin{array}{c}-0.039^{* *} \\
(0.018)\end{array}$ \\
\hline Bk Branches & & $\begin{array}{l}-0.16^{* * *} \\
(0.0086)\end{array}$ & $\begin{array}{l}-0.24^{* * *} \\
(0.0093)\end{array}$ \\
\hline Log Med. Inc. & & & $\begin{array}{l}0.18^{* * *} \\
(0.021)\end{array}$ \\
\hline Frac Commute $45+\mathrm{m}$ & & & $\begin{array}{l}1.00^{* * *} \\
(0.086)\end{array}$ \\
\hline Frac White & & & $\begin{array}{c}-0.79^{* * *} \\
(0.049)\end{array}$ \\
\hline Log Pop & & & $\begin{array}{c}0.20^{* * *} \\
(0.0088)\end{array}$ \\
\hline Constant & $\begin{array}{c}-2.26^{* * *} \\
(0.077)\end{array}$ & $\begin{array}{c}-2.12^{* * *} \\
(0.075)\end{array}$ & $\begin{array}{c}-5.35^{* * *} \\
(0.22)\end{array}$ \\
\hline $\begin{array}{l}\text { Observations } \\
R^{2} \\
\text { County FEs }\end{array}$ & $\begin{array}{l}12695 \\
0.812 \\
\mathrm{X}\end{array}$ & $\begin{array}{l}12695 \\
0.822 \\
X\end{array}$ & $\begin{array}{c}12547 \\
0.863 \\
\text { X }\end{array}$ \\
\hline \multicolumn{4}{|c|}{$\begin{array}{l}\text { ZIP code level specifications showing the relationship between the } \\
\text { share of PPP lending per establishment and the predicted level of } \\
\text { PPP lending based on banks' overall degree of PPP lending. Ro- } \\
\text { bust standard errors. Estimates are weighted by establishments } \\
\text { per ZIP code. Weighting by PPP loans per ZIP code or using } \\
\text { log(PPP/Establishments) as a dependent variable yields similar re- } \\
\text { sults. Data calculated from ZIP business patterns and SBA PPP loan } \\
\text { data. }\end{array}$} \\
\hline
\end{tabular}




\section{A Appendix}

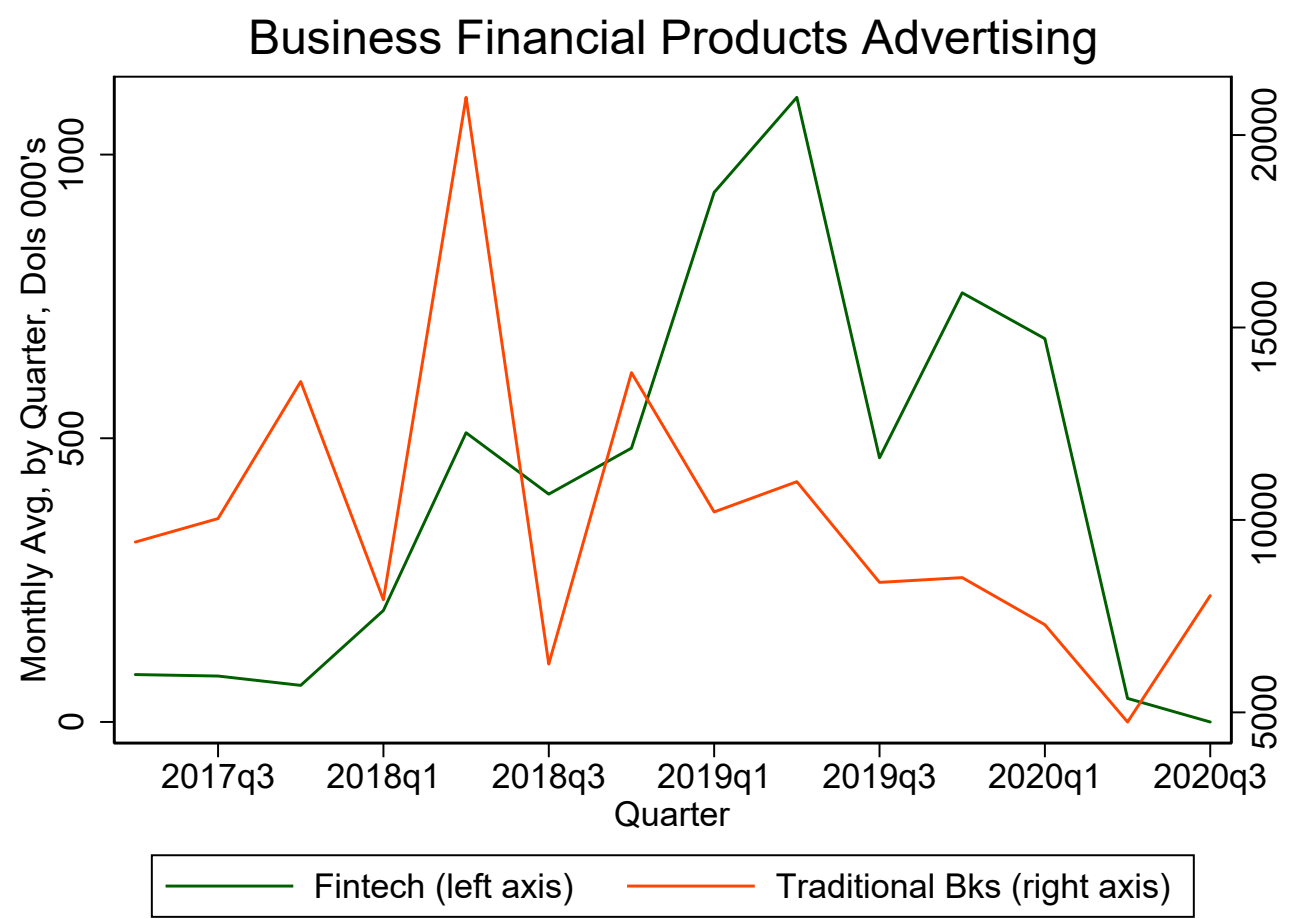

Figure A1: Commercial and Business Financial Services Advertising Dollars by FinTech and Non-Fintech Lenders. "FinTech" includes the top-30 FinTech PPP lenders. Monthly averages by quarter through July, 2020. Source: Compiled using data from Kantar Media. 
Table A1: Summary Statistics by ZIP Code (unweighted)

\begin{tabular}{lcccc}
\hline & & & & \\
& Mean & Std. Dev & Median & Count \\
\hline Frac Nonbank & 0.05 & 0.10 & 0.01 & 36,675 \\
Frac Online Bk & 0.06 & 0.10 & 0.02 & 36,675 \\
Total FinTech PPP Fraction & 0.10 & 0.15 & 0.06 & 36,675 \\
Frac Bk/CU & 0.88 & 0.16 & 0.92 & 36,675 \\
Num. PPP Lns & 142.12 & 262.93 & 26.00 & 36,675 \\
Median Income & $59,457.12$ & $25,252.21$ & $54,286.00$ & 30,002 \\
Frac. 45m+ Commute & 0.17 & 0.12 & 0.15 & 31,190 \\
Frac. White & 0.83 & 0.20 & 0.92 & 31,501 \\
Total Pop & $4,558.81$ & $6,742.19$ & $1,306.00$ & 31,565 \\
Num. Bk Branches & 4.53 & 4.90 & 3.00 & 19,404 \\
Avg COVID Case Rate & 0.01 & 0.02 & 0.00 & 35,749 \\
Unemp. Growth & 2.95 & 1.79 & 2.63 & 17,176 \\
Num. Estabs & 230.15 & 403.82 & 45.00 & 33,955 \\
\hline
\end{tabular}

Bank branches are for ZIP codes that have at least one branch. Unemployment data is not available for all regions. Source: Calculated from SBA PPP database, FDIC SOD, Decennial Census/ACS, County Business Patterns. 
Table A2: Number of Branches in the ZIP Code and PPP Lending Shares, Alternative Measure of FinTech

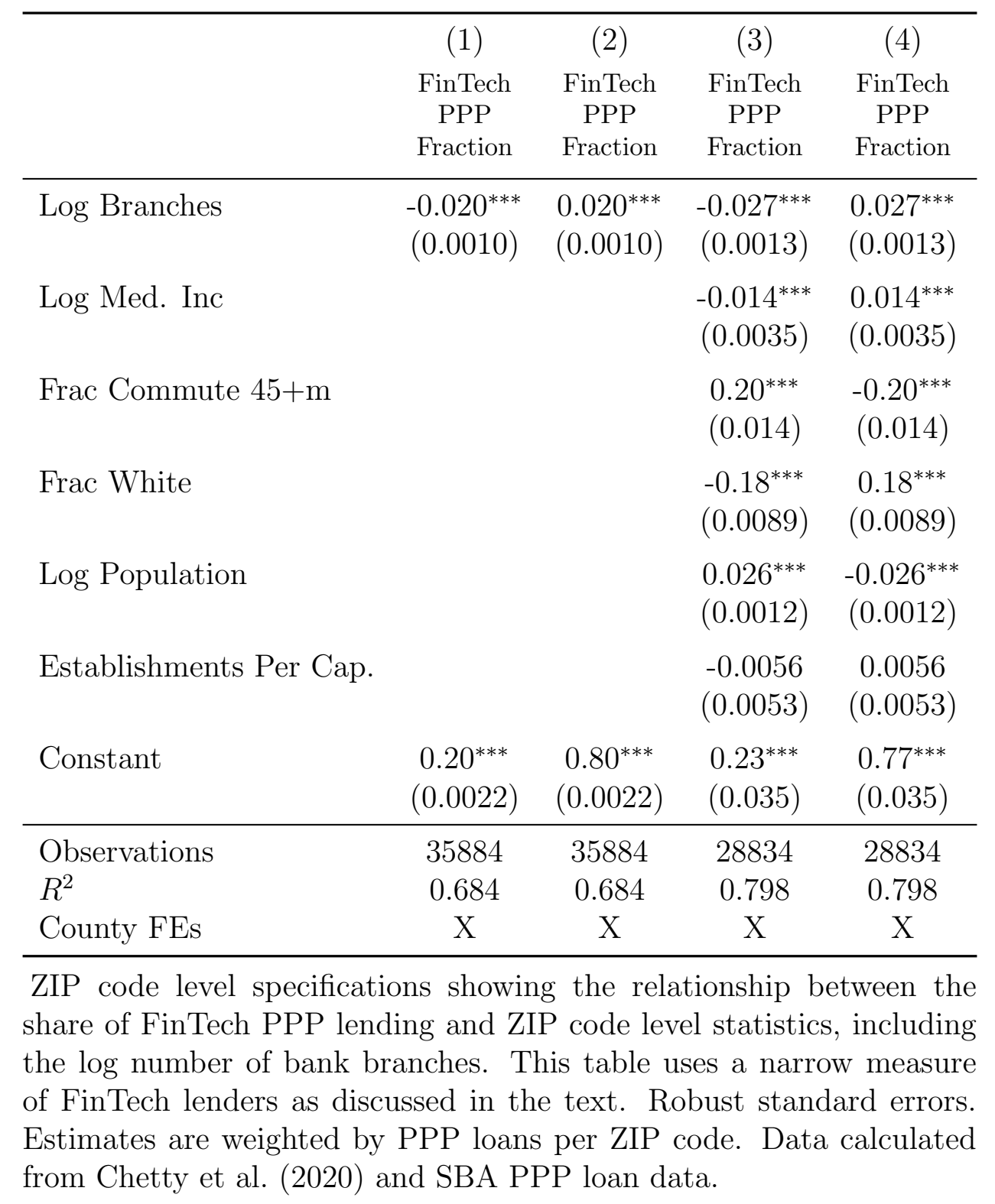


Table A3: Number of Branches in the ZIP Code and PPP Lending Shares, Online and Nonbank Lenders

\begin{tabular}{lcccc}
\hline & $(1)$ & $(2)$ & $(3)$ & $(4)$ \\
& $\begin{array}{c}\text { Online Bk } \\
\text { PPP } \\
\text { Fraction }\end{array}$ & $\begin{array}{c}\text { Nonbank } \\
\text { PPP } \\
\text { Fraction }\end{array}$ & $\begin{array}{c}\text { Online Bk } \\
\text { PPP } \\
\text { Fraction }\end{array}$ & $\begin{array}{c}\text { Nonbank } \\
\text { PPP } \\
\text { Fraction }\end{array}$ \\
\hline Log Branches & $-0.0063^{* * *}$ & $-0.012^{* * *}$ & $-0.010^{* * *}$ & $-0.015^{* * *}$ \\
& $(0.00054)$ & $(0.00057)$ & $(0.00068)$ & $(0.00070)$ \\
Log Med. Inc & & & $-0.0065^{* * *}$ & $-0.0058^{* * *}$ \\
& & & $(0.0020)$ & $(0.0018)$ \\
Frac Commute 45+m & & & $0.086^{* * *}$ & $0.10^{* * *}$ \\
& & & $(0.0083)$ & $(0.0075)$ \\
Frac White & & & $-0.070^{* * *}$ & $-0.11^{* * *}$ \\
& & & $(0.0051)$ & $(0.0046)$ \\
Log Population & & & $0.013^{* * *}$ & $0.012^{* * *}$ \\
& & & $-0.00063)$ & $(0.00064)$ \\
Establishments Per Cap. & & & $(0.0026)$ & -0.0011 \\
& & & $0.0029)$ \\
Constant & $0.11^{* * *}$ & $0.093^{* * *}$ & $0.11^{* * *}$ & $0.11^{* * *}$ \\
& $(0.0011)$ & $(0.0012)$ & $(0.020)$ & $(0.019)$ \\
\hline Observations & 35937 & 35937 & 28850 & 28850 \\
$R^{2}$ & 0.740 & 0.618 & 0.805 & 0.743 \\
County FEs & $\mathrm{X}$ & $\mathrm{X}$ & $\mathrm{X}$ & $\mathrm{X}$ \\
\hline
\end{tabular}

ZIP code level specifications showing the relationship between the share of online and nonbank PPP lending and ZIP code level statistics, including the log number of bank branches. Robust standard errors. Estimates are weighted by PPP loans per ZIP code. Data calculated from Chetty et al. (2020) and SBA PPP loan data. 
Table A4: Bank Branch Density and Fraction of Online/Nonbank Loans, Loan Level Estimates

\begin{tabular}{lcc}
\hline & $(1)$ & $(2)$ \\
& FinTech & FinTech \\
& Loan & PPP \\
& Loan \\
\hline Log Bk Branches & $-0.022^{* * *}$ & $-0.019^{* * *}$ \\
& $(0.0012)$ & $(0.00096)$ \\
Frac White & $-0.21^{* * *}$ & $-0.18^{* * *}$ \\
& $(0.0068)$ & $(0.0056)$ \\
Frac Commute 45+m & $0.14^{* * *}$ & $0.12^{* * *}$ \\
& $(0.013)$ & $(0.011)$ \\
Log Pop & $0.025^{* * *}$ & $0.019^{* * *}$ \\
& $(0.00092)$ & $(0.00077)$ \\
Log Est Size & $-0.022^{* * *}$ & $-0.014^{* * *}$ \\
& $(0.0016)$ & $(0.0013)$ \\
Constant & $0.16^{* * *}$ & $0.18^{* * *}$ \\
& $(0.010)$ & $(0.0086)$ \\
\hline Observations & 5116435 & 4988784 \\
$R^{2}$ & 0.080 & 0.172 \\
County FEs & $\mathrm{X}$ & $\mathrm{X}$ \\
NAICS FEs & & $\mathrm{X}$ \\
\hline Loan level specifcation & &
\end{tabular}

Loan level specifications showing the relationship between the likelihood that a PPP loan is from an online bank/nonbank, and ZIP code level statistics, including the log number of bank branches. Standard errors clustered by ZIP Code. Data calculated from the SBA PPP Loan Database, ZIP Business Patterns, the 2014-2018 ACS and the 2010 Decennial Census. 
Table A5: Predicted Bank Lending and the Economic Shock

\begin{tabular}{lcccc}
\hline & $(1)$ & $(2)$ & $(3)$ & $(4)$ \\
& $\begin{array}{c}\text { Average } \\
\text { Case Rate }\end{array}$ & $\begin{array}{c}\text { Average } \\
\text { Case Rate }\end{array}$ & $\begin{array}{c}\text { Unemployment } \\
\text { Growth }\end{array}$ & $\begin{array}{c}\text { Unemployment } \\
\text { Growth }\end{array}$ \\
\hline Log Pred. PPP & -0.000082 & -0.00055 & -0.030 & -0.026 \\
& $(0.00043)$ & $(0.00044)$ & $(0.050)$ & $(0.050)$ \\
Bk Branches & & $0.0012^{* * *}$ & & -0.011 \\
& & $(0.00024)$ & & $(0.022)$ \\
Constant & $0.013^{* * *}$ & $0.012^{* * *}$ & $3.24^{* * *}$ & $3.25^{* * *}$ \\
& $(0.0016)$ & $(0.0016)$ & $(0.18)$ & $(0.18)$ \\
\hline Observations & 13690 & 13690 & 6819 & 6819 \\
$R^{2}$ & 0.852 & 0.853 & 0.792 & 0.792 \\
Commuting Zone FEs & & $\mathrm{X}$ & & $\mathrm{X}$ \\
\hline
\end{tabular}

ZIP code-by-bank level specifications showing the relationship between the predicted number of bank PPP loans, and the magnitude of the COVID-19 economic shock. Robust standard errors. Estimates are weighted by PPP loans per ZIP code. Data calculated from the FDIC Summary of Deposits database, SBA PPP loan data, and data from Chetty et al. (2020). 
Table A6: PPP Lending and Bank's Own Branch Locations

\begin{tabular}{|c|c|c|c|}
\hline & $(1)$ & $(2)$ & $(3)$ \\
\hline & $\begin{array}{l}\text { Log PPP } \\
\text { Loans }\end{array}$ & $\begin{array}{l}\text { Log PPP } \\
\text { Loans }\end{array}$ & $\begin{array}{l}\text { Log PPP } \\
\text { Loans }\end{array}$ \\
\hline Bk Branches & $\begin{array}{l}2.12^{* * *} \\
(0.070)\end{array}$ & $\begin{array}{l}1.87^{* * *} \\
(0.099)\end{array}$ & $\begin{array}{l}1.99^{* * *} \\
(0.046)\end{array}$ \\
\hline Constant & $\begin{array}{l}1.36^{* * *} \\
(0.086)\end{array}$ & $\begin{array}{l}1.64^{* * *} \\
(0.093)\end{array}$ & $\begin{array}{l}1.47^{* * *} \\
(0.036)\end{array}$ \\
\hline $\begin{array}{l}\text { Observations } \\
R^{2} \\
\text { Bank FEs } \\
\text { Zip FEs }\end{array}$ & $\begin{array}{l}58556 \\
0.147\end{array}$ & $\begin{array}{l}52360 \\
0.399\end{array}$ & $\begin{array}{c}57885 \\
0.438 \\
\text { X }\end{array}$ \\
\hline \multicolumn{4}{|c|}{$\begin{array}{l}\text { ZIP code-by-bank level specifications show- } \\
\text { ing the relationship between the number of } \\
\text { PPP loans from a given bank, and the num- } \\
\text { ber of branches that that bank has in the ZIP } \\
\text { code. Robust standard errors. Estimates are } \\
\text { weighted by PPP loans per ZIP code. Data } \\
\text { calculated from the FDIC Summary of De- } \\
\text { posits database and SBA PPP loan data. }\end{array}$} \\
\hline
\end{tabular}


Table A7: Effect of Predicted Bank Lending on Overall Lending

\begin{tabular}{lcccccc}
\hline & $\begin{array}{c}(1) \\
\text { Log PPP } \\
\text { Loans }\end{array}$ & $\begin{array}{c}\text { Log PPP } \\
\text { Loans }\end{array}$ & $\begin{array}{c}\text { Log PPP } \\
\text { Loans }\end{array}$ & $\begin{array}{c}\text { Log PPP } \\
\text { Loans }\end{array}$ & $\begin{array}{c}\text { Log PPP } \\
\text { Loans }\end{array}$ & $\begin{array}{c}\text { Log PPP } \\
\text { Loans }\end{array}$ \\
\hline Bk Branches & $0.83^{* * *}$ & $0.72^{* * *}$ & $0.83^{* * *}$ & $0.72^{* * *}$ & $0.83^{* * *}$ & $0.72^{* * *}$ \\
& $(0.012)$ & $(0.0099)$ & $(0.012)$ & $(0.0099)$ & $(0.012)$ & $(0.0099)$ \\
Log Predicted PPP (Winsor 90) & $0.51^{* * *}$ & $0.15^{* * *}$ & & & & \\
& $(0.026)$ & $(0.028)$ & & & & \\
Log Predicted PPP (Winsor 95) & & & $0.42^{* * *}$ & $0.12^{* * *}$ & & \\
& & & $(0.023)$ & $(0.025)$ & & \\
Log Predicted PPP (Winsor 100) & & & & & $0.32^{* * *}$ & $0.093^{* * *}$ \\
& & & & & $(0.021)$ & $(0.021)$ \\
Constant & $2.55^{* * *}$ & $4.15^{* * *}$ & $2.87^{* * *}$ & $4.25^{* * *}$ & $3.24^{* * *}$ & $4.34^{* * *}$ \\
& $(0.095)$ & $(0.10)$ & $(0.088)$ & $(0.092)$ & $(0.078)$ & $(0.077)$ \\
\hline Observations & 13841 & 13814 & 13841 & 13814 & 13841 & 13814 \\
$R^{2}$ & 0.510 & 0.789 & 0.507 & 0.789 & 0.502 & 0.789 \\
County FEs & & $\mathrm{X}$ & & $\mathrm{X}$ & & $\mathrm{X}$ \\
\hline
\end{tabular}

ZIP code-by-bank level specifications showing the relationship between the predicted number of bank PPP loans, and the total overall number of PPP loans. The PPP measures are Winsorized at the bank level before weighted averages are calculated at the ZIP code level, as discussed in the text. Robust standard errors. Estimates are weighted by PPP loans per ZIP code. Data calculated from the FDIC Summary of Deposits database and SBA PPP loan data. 
Table A8: Effect of Predicted Bank PPP on Total PPP Per Establishment, Phase 2 Only

\begin{tabular}{lccc}
\hline & $(1)$ & $(2)$ & $(3)$ \\
& $\begin{array}{c}\text { FinTech PPP / } \\
\text { Establishments }\end{array}$ & $\begin{array}{c}\text { FinTech PPP/ } \\
\text { Establishments }\end{array}$ & $\begin{array}{c}\text { FinTech PPP/ } \\
\text { Establishments }\end{array}$ \\
\hline Log Pred. PPP & $-0.11^{* * *}$ & $-0.041^{*}$ & $-0.036^{*}$ \\
& $(0.022)$ & $(0.021)$ & $(0.019)$ \\
Bk Branches & & $-0.18^{* * *}$ & $-0.27^{* * *}$ \\
& & $(0.0090)$ & $(0.0096)$ \\
Log Med. Inc. & & & $0.16^{* * *}$ \\
Frac Commute 45+m & & & $(0.022)$ \\
Frac White & & & $1.08^{* * *}$ \\
& & & $(0.091)$ \\
Log Pop & & & $-0.84^{* * *}$ \\
& & & $(0.050)$ \\
Constant & & & $0.22^{* * *}$ \\
& & & $(0.0092)$ \\
\hline Observations & & & $-5.40^{* * *}$ \\
$R^{2}$ & 12574 & 12574 & $(0.22)$ \\
\hline & 0.802 & 0.814 & 12433 \\
\hline
\end{tabular}

ZIP code level specifications showing the relationship between the share of PPP lending per establishment and the predicted level of PPP lending based on banks' overall degree of PPP lending. Dependent variable is limited to PPP loans made during Phase 2 of the program. Robust standard errors. Estimates are weighted by establishments per ZIP code. Weighting by PPP loans per ZIP code or using $\log (\mathrm{PPP} /$ Establishments $)$ as a dependent variable yields similar results. Data calculated from ZIP business patterns and SBA PPP loan data. 


\section{B Lender Classifications}

B.1 Non-Bank FinTech Lenders 


\begin{tabular}{lc}
\hline Nonbank Lender & PPP Loans \\
\hline Kabbage, Inc. & 196402 \\
Readycap Lending, LLC & 34261 \\
MBE Capital Partners & 23945 \\
Intuit Financing Inc. & 19086 \\
Fundbox, Inc. & 14281 \\
Newtek Small Business Finance, Inc. & 11677 \\
New York Business Development Corporation & 6468 \\
FC Marketplace, LLC (dba Funding Circle) & 6235 \\
Harvest Small Business Finance, LLC & 5353 \\
CDC Small Business Finance Corporation & 4095 \\
BSD Capital, LLC dba Lendistry & 4076 \\
Itria Ventures LLC & 3556 \\
Fountainhead SBF LLC & 3453 \\
Hope Enterprise Corporation & 2869 \\
Accion & 2483 \\
CRF Small Business Loan Company, LLC & 2398 \\
Fund-Ex Solutions Group, LLC & 1416 \\
Montana Community Development Corp. & 1276 \\
Mortgage Capital Development Corporation & 1122 \\
LiftFund, Inc. & 1036 \\
Opportunity Fund Community Development & 990 \\
Prestamos CDFI, LLC & 938 \\
Centerstone SBA Lending, Inc. & 898 \\
Trenton Business Assistance Corporation & 894 \\
Benworth Capital & 779 \\
Colorado Enterprise Fund & 779 \\
Arkansas Capital Corporation & 771 \\
Grow America Fund, Incorporated & 715 \\
Colorado Lending Source, Ltd. & 612 \\
Accion East, Inc. & 560 \\
American Lending Center & 555 \\
Hana Small Business Lending, Inc. & 504 \\
\hline
\end{tabular}




\section{B.2 Online Bank FinTech Lenders}

\begin{tabular}{lc}
\hline Online Bank Lender & PPP Loans \\
\hline Cross River Bank & 198738 \\
Celtic Bank Corporation & 147317 \\
WebBank & 76578 \\
Capital One, National Association & 15772 \\
Live Oak Banking Company & 11045 \\
American Express National Bank & 6964 \\
Signature Bank & 6311 \\
Radius Bank & 6224 \\
First Bank of the Lake & 4199 \\
Transportation Alliance Bank, Inc. d/b/a TAB Bank, Inc. & 1687 \\
Pacific Enterprise Bank & 1388 \\
The Bancorp Bank & 1288 \\
Savoy Bank & 1165 \\
American Business Bank & 1072 \\
First Secure Bank and Trust Co. & 1033 \\
Union National Bank & 956 \\
Ally Bank & 943 \\
T Bank, National Association & 922 \\
Primary Bank & 918 \\
Endeavor Bank & 860 \\
The MINT National Bank & 859 \\
LCA Bank Bank Corporation & 853 \\
Signature Bank, National Associatioin & 825 \\
Vinings Bank & 777 \\
\hline & 740 \\
\hline
\end{tabular}




\begin{tabular}{lc}
\hline Online Bank Lender & PPP Loans \\
\hline FinWise Bank & 699 \\
St. Louis Bank & 674 \\
Solera National Bank & 665 \\
Fresno First Bank & 656 \\
Optus Bank & 641 \\
Continental Bank & 635 \\
Loyal Trust Bank & 626 \\
First Command Bank & 621 \\
Lexicon Bank & 616 \\
Keystone Bank, National Association & 612 \\
Chain Bridge Bank, National Association & 588 \\
The Victory Bank & 579 \\
Bankers' Bank of Kansas & 559 \\
Bank of San Francisco & 542 \\
Buckeye State Bank & 531 \\
Beacon Community Bank & 522 \\
Small Business Bank & 520 \\
New Valley Bank and Trust & 519 \\
TIAA Bank, A Division of & 273 \\
\hline
\end{tabular}




\section{B.3 Online Bank FinTech Lenders, Alternative Definition}

\begin{tabular}{lc}
\hline Lender & PPP Loans \\
\hline Cross River Bank & 198738 \\
Celtic Bank Corporation & 147317 \\
WebBank & 76578 \\
Capital One, National Association & 15772 \\
American Express National Bank & 6964 \\
Radius Bank & 6224 \\
The Bancorp Bank & 1288 \\
Ally Bank & 943 \\
Axos Bank & 853 \\
OneWest Bank, A Division of & 840 \\
FinWise Bank & 699 \\
First Internet Bank of Indiana & 447 \\
TIAA Bank, A Division of & 273 \\
Green Dot Bank & 17 \\
\hline
\end{tabular}




\section{Variable Definitions}

\begin{tabular}{|c|c|c|}
\hline Variable & Source & Description \\
\hline Frac Nonbank & SBA PPP Database & $\begin{array}{l}\text { Frac from lenders with above } 750 \text { loans } \\
\text { with no match in the FFIEC Attributes } \\
\text { File or otherwise using news reports. }\end{array}$ \\
\hline Frac Online Bk & SBA PPP Database & $\begin{array}{l}\text { Frac from lenders with one branch and } \\
\text { at least } 500 \text { PPP loans or identified using } \\
\text { news reports. }\end{array}$ \\
\hline $\begin{array}{l}\text { Total FinTech } \\
\text { PPP Fraction }\end{array}$ & SBA PPP Database & $\begin{array}{l}\text { Fraction from either nonbank or online } \\
\text { bank PPP lenders. }\end{array}$ \\
\hline One-Pers. Firm & SBA PPP Database & $\begin{array}{l}\text { Indicator equal to } 1 \text { for borrowers with } \\
\text { business type "Sole Proprietorship" or } \\
\text { "Self-Employed Individuals" }\end{array}$ \\
\hline $\begin{array}{l}\text { Frac Traditional } \\
\mathrm{Bk} / \mathrm{CU}\end{array}$ & SBA PPP Database & $\begin{array}{l}\text { Fraction of loans from non-FinTech } \\
\text { lenders that match to FFIEC Attributes } \\
\text { file. }\end{array}$ \\
\hline Median Income & $\begin{array}{l}\text { American Community } \\
\text { Survey, 2014-2018 }\end{array}$ & Median Income \\
\hline $\begin{array}{l}\text { Frac } 45 \mathrm{~m}+ \\
\text { Commute }\end{array}$ & $\begin{array}{l}\text { American Community } \\
\text { Survey, 2014-2018 }\end{array}$ & $\begin{array}{l}\text { Fraction of } \mathrm{HHs} \text { with commute time } \\
\text { greater than or equal to } 45 \text { minutes }\end{array}$ \\
\hline Frac. White & $\begin{array}{l}\text { American Community } \\
\text { Survey, 2014-2018 }\end{array}$ & $\begin{array}{l}\text { Fraction of individuals reporting "White" } \\
\text { as only race }\end{array}$ \\
\hline Total Pop & $\begin{array}{l}\text { American Community } \\
\text { Survey, 2014-2018 }\end{array}$ & Total population \\
\hline $\begin{array}{l}\text { Fraction w Desk- } \\
\text { top }\end{array}$ & $\begin{array}{l}\text { American Community } \\
\text { Survey, 2014-2018 }\end{array}$ & Fraction of HHs with desktop computer \\
\hline $\begin{array}{l}\text { Num. } \\
\text { Branches }\end{array}$ & $\begin{array}{l}\text { FDIC Summary of De- } \\
\text { posits Database }\end{array}$ & Number of bank branches in ZIP code \\
\hline Avg COVID & The New York Times, as & Avg number of active COVID cases per \\
\hline Case Rate & $\begin{array}{l}\text { collected by Chetty et al. } \\
(2020)\end{array}$ & 100 people in March, by county \\
\hline $\begin{array}{l}\text { Unempl. } \\
\text { Growth }\end{array}$ & $\begin{array}{l}\text { State Agencies, as col- } \\
\text { lected by Chetty et al. } \\
(2020)\end{array}$ & $\begin{array}{l}\text { Four-week change in unemployment in- } \\
\text { surance claims as of April 11, 2020, by } \\
\text { County }\end{array}$ \\
\hline Num. Estabs & ZIP Business Patterns & $\begin{array}{l}\text { Number of establishments in ZIP Code, } \\
2017\end{array}$ \\
\hline $\mathrm{PPP} / \mathrm{SBA} 7(\mathrm{a})$ & $\begin{array}{l}\text { SBA PPP and } 7(\mathrm{a}) \\
\text { databases }\end{array}$ & $\begin{array}{l}\text { Ratio of PPP loans to SBA } 7(\text { a) loans } \\
\text { from 2018-2019, by NAICS 5-digit indus- } \\
\text { try }\end{array}$ \\
\hline & & Continued on next page \\
\hline
\end{tabular}


Table A9 - continued from previous page

\begin{tabular}{|l|l|l|}
\hline \multicolumn{1}{|c|}{ Variable } & \multicolumn{1}{|c|}{ Source } & \multicolumn{1}{c|}{ Description } \\
\hline $\begin{array}{l}\text { Fraction of 7(a) } \\
\text { loans from Fin- } \\
\text { Tech }\end{array}$ & SBA 7(a) data & $\begin{array}{l}\text { Fraction of 7(a) loans where lender name } \\
\text { matches a PPP FinTech lender }\end{array}$ \\
\hline
\end{tabular}

